J. Dairy Sci. 99:3549-3565

http://dx.doi.org/10.3168/jds.2015-10450

(C) American Dairy Science Association ${ }^{\circledR}, 2016$.

\title{
The effects of a ration change from a total mixed ration to pasture on rumen fermentation, volatile fatty acid absorption characteristics, and morphology of dairy cows
}

\author{
M. Schären, ${ }^{*}$ G. M. Seyfang,† H. Steingass,† K. Dieho,‡ J. Dijkstra,‡ L. Hüther, ${ }^{*}$ J. Frahm, ${ }^{*}$ A. Beineke,§ \\ D. von Soosten, ${ }^{*}$ U. Meyer, ${ }^{* 1}$ G. Breves,\# and S. Dänicke* \\ *Institute of Animal Nutrition, Friedrich-Loeffler-Institute, Federal Research Institute for Animal Health, Bundesallee 50, \\ 38116 Brunswick, Germany \\ †Institute of Animal Science, University of Hohenheim, Emil-Wolff-Str. 10, 70599 Stuttgart, Germany \\ $\ddagger$ Animal Nutrition Group, Wageningen University, De Elst 1, 6708WD Wageningen, the Netherlands \\ §Institute of Pathology, University of Veterinary Medicine Hanover, Bünteweg 17, 30559 Hannover, Germany \\ \#Department of Physiology, University of Veterinary Medicine Hanover, Bischofsholer Damm 15, 30173 Hannover, Germany
}

\begin{abstract}
To investigate the effect of the change from a concentrate and silage-based ration (total mixed ration, TMR) to a pasture-based ration, a 10-wk trial (wk 1-10) was performed, including 10 rumen- and duodenum-fistulated German Holstein dairy cows $(182 \pm 24$ $\mathrm{d}$ in milk, $23.5 \pm 3.5 \mathrm{~kg}$ of milk/d; mean \pm standard deviation). The cows were divided in either a pasture group $(\mathrm{PG}, \mathrm{n}=5)$ or a confinement group $(\mathrm{CG}, \mathrm{n}=$ $5)$. The $\mathrm{CG}$ stayed on a TMR-based ration $(35 \%$ corn silage, $35 \%$ grass silage, $30 \%$ concentrate; dry matter basis), whereas the $\mathrm{PG}$ was gradually transitioned from a TMR to a pasture-based ration (wk 1: TMR only; wk $2: 3 \mathrm{~h} / \mathrm{d}$ on pasture wk 3 and $4: 12 \mathrm{~h} / \mathrm{d}$ on pasture wk 5-10: pasture only). Ruminal $\mathrm{pH}$, volatile fatty acids (VFA), $\mathrm{NH}_{3}-\mathrm{N}$, and lipopolysaccharide (LPS) concentrations were measured in rumen fluid samples collected medially and ventrally on a weekly basis. Ruminal $\mathrm{pH}$ was continuously recorded during 1 to 4 consecutive days each week using ruminal $\mathrm{pH}$ measuring devices. In wk 1,5 , and 10 , rumen contents were evacuated and weighed, papillae were collected from 3 locations in the rumen, and subsequently a VFA absorption test was performed. In the PG, mean rumen $\mathrm{pH}$ and molar acetate proportions decreased, and molar butyrate proportions increased continuously over the course of the trial, which can most likely be ascribed to an increased intake of rapidly fermentable carbohydrates. During the first weeks on a full grazing ration (wk 5-7), variation of rumen $\mathrm{pH}$ decreased, and in wk 5 a lower rumen content, papillae surface area, and potential for VFA absorption were observed.
\end{abstract}

\footnotetext{
Received September 27, 2015.

Accepted January 3, 2016.

${ }^{1}$ Corresponding author: Ulrich.Meyer@fli.bund.de
}

In wk 8 to 10 , variation of rumen $\mathrm{pH}$ and total VFA concentrations increased again, and acetate/propionate ratio decreased. In wk-10 rumen content, papillae area and VFA absorption characteristics similar to initial levels were observed. Although continuous rumen $\mathrm{pH}$ assessments and LPS concentrations did not reveal an increased risk for subacute rumen acidosis (SARA) during the adaption period, histopathology of rumen papillae and potential for VFA absorption indicated a possible risk for rumen health. An increased risk for SARA was observed in wk 9 and 10 in the PG, but rumen LPS concentrations and histopathology were not adversely affected. Results of the present study suggest that after behavioral and metabolic adaptation to the transition from a TMR to a pasture-based ration, no adverse effects on rumen morphology and absorption capacity occurred, although rumen $\mathrm{pH}$ after adaptation to pasture indicated increased risk of SARA.

Key words: pasture, ration change, rumen papillae morphology, rumen volatile fatty acid absorption characteristics

\section{INTRODUCTION}

Upon transition from a silage and concentrate- to a pasture-based diet, dairy cattle and their rumen microbiota need to adapt to this new nutritional situation (de Menezes et al., 2011; Nakano et al., 2013). Dry matter intake is generally lower in pasture-based systems due to physical constraints, and energy expenditure is higher due to grazing and walking activity (Osuji, 1974; Kolver, 2003). The ration composition differs considerably between the 2 systems (Kolver, 2003) with the pasture-based ration generally characterized by a higher CP and water-soluble carbohydrate (WSC) content and lower starch content (Kolver and de Veth, 2002; Kolver, 2003). Additionally, protein and energy 
availability in pasture-based rations are subjected to seasonal, weekly, and even daily variations caused by changes in plant maturity and weather, as well as management decisions (Parker and Edwards, 1996; Mayne et al., 2000; Smit et al., 2004).

Few studies have investigated the difference in rumen fermentation patterns comparing TMR and pasture-fed dairy cows. Generally higher rumen ammonia concentrations were observed when a pasture-based ration was fed, but results are inconclusive regarding ruminal $\mathrm{pH}$ and VFA concentrations (Holden et al., 1994; Bargo et al., 2002a,b). Rumen digesta stratification and intraruminal differences in $\mathrm{pH}$ and VFA concentration are influenced by feed fiber content and particle length (Storm and Kristensen, 2010). Diets with a higher fiber content and longer particle length promote ruminal stratification (Tafaj et al., 2004; Storm and Kristensen, 2010). Storm and Kristensen (2010) hypothesized that feeding a low fiber diet could result in a more homogenous ruminal content and thereby increasing ventral VFA concentrations and increasing the risk of ruminal acidosis. Because high-quality pastures are often low in physical effective fiber and high in concentrations of WSC, pasture-based rations may adversely affect rumen fermentation and $\mathrm{pH}$ (Kolver and de Veth, 2002; O'Grady et al., 2008). Bramley et al. (2008) and O'Grady et al. (2008) showed that approximately $10 \%$ of cows in pasture-based systems could be classified as being affected by SARA. Most research investigating the relationship of a low ruminal $\mathrm{pH}$ and adverse effects on health and production has been conducted in confinement TMR-based systems (Plaizier et al., 2008), and it is unclear if the developed cut-off values for SARA can be translated onto pasture-based systems. Kolver and de Veth (2002) suggested that a low ruminal pH arising from high fermentable OM (fOM) intake and low physical effective fiber does not necessarily compromise cow performance on pasture. This is further supported by several recent studies showing that the consequences of SARA are possibly substrate dependent (Khafipour et al., 2009a,b; Calsamiglia et al., 2012).

Ruminal $\mathrm{pH}$ and fermentation patterns are just one aspect of different rumen characteristics that are possibly influenced by a ration change. Also, rumen papillae morphology and absorption capacity (Bannink et al., 2012; Martens et al., 2012; Dieho et al., 2016), histology (Steele et al., 2011; Bannink et al., 2012), and gene expression (Connor et al., 2010; Penner et al., 2011; Steele et al., 2012) are altered under the influence of different ration types and during SARA. For example, slowly increasing the concentrate intake leads to an increase in the size of the papillae and the number of epithelial cells (Dirksen et al., 1984; Liebich et al., 1987). In fooddeprived animals, a decrease in fermentable substrate leads to a decrease in absorptive capacity of the rumen wall (Gäbel et al., 1993).

Generally, the transition from one ration type to another causes changes in the rumen microbiota (Russell and Rychlik, 2001) and rumen stratification (Storm and Kristensen, 2010), which leads to alterations in fermentation patterns (Van Houtert, 1993) and to physiological and structural adaptations of the rumen epithelium (Gäbel et al., 2002). Up to now, not much research has focused on the effect of a transition from a TMR to a pasture-based ration on rumen fermentation, VFA absorption capacity, and morphology as well as the length required for adaptation. Because these 2 systems do not only differ substantially in ration composition, but also in the way feed is acquired, we hypothesize that the change from a confinement TMR to a pasture-based system involves complex physiological and structural adaptations of the rumen. We suggest that a pasturebased ration in a continuous grazing system with a relatively short herbage height could lead to smaller intraruminal differences with regard to stratification and fermentation due to its possible lower fiber content and particle length. Further, a high content of fast fermentable carbohydrates and low amount of physical effective fiber could increase the risk for SARA and have adverse effects on rumen epithelium. The aim of the present study was therefore to investigate the influence of the transition from a TMR to a pasture-based diet on several rumen variables including the total rumen content and rumen fermentation characteristics ( $\mathrm{pH}, \mathrm{VFA}, \mathrm{NH}_{3}-\mathrm{N}$, and LPS concentrations), and on VFA absorption as well as on morphological variables including papillae surface area and histopathological parameters.

\section{MATERIALS AND METHODS}

Experimental work was conducted at the experimental station of the Friedrich Loeffler Institute in Brunswick, Germany. The experiment was carried out in accordance with the German Animal Welfare Act approved by the Lower Saxony State Office for Consumer Protection and Food Safety, Germany.

\section{Experimental Design and Treatments}

The experimental design, treatments, rations, climate data, animal performance, urine variables, clinical chemistry, and total blood counts were reported in Schären et al. (2016). In brief, the full trial included 60 German Holstein cows $(166 \pm 23$ DIM and $23.5 \pm$ $3.7 \mathrm{~kg}$ of milk/d; parity: $1.9 \pm 1.6$; mean $\pm \mathrm{SD}$; at the beginning of the trial) that were randomly assigned to either a pasture group (PG; $\mathrm{n}=29)$ or a confinement 
group $(\mathbf{C G} ; \mathrm{n}=31)$. Each group contained 5 rumenand duodenum-fistulated animals (182 \pm 24 DIM, 23.5 $\pm 3.5 \mathrm{~kg}$ milk $/ \mathrm{d}$; parity: $4.5 \pm 2.2$; mean $\pm \mathrm{SD}$; at the beginning of the trial). The experimental work and data describing rumen variables in the present paper have been exclusively conducted and collected in these 10 animals. The experimental period lasted $10 \mathrm{wk}$ (wk 1-10) from April 21 until June 27, 2014. The CG stayed on a TMR-based ration (35\% corn silage, $35 \%$ grass silage, $30 \%$ concentrate; DM basis), whereas the PG was transitioned from a TMR to a pasture-based ration (wk 1: TMR only; wk 2: TMR and $3 \mathrm{~h} / \mathrm{d}$ on pasture; wk 3 and 4: TMR and $12 \mathrm{~h} / \mathrm{d}$ on pasture; and wk 5-10: pasture and $1.75 \mathrm{~kg}$ of DM concentrate/d offered in 2 equal meals in troughs after morning and evening milking). A continuous grazing system was implemented on ryegrass-dominated pasture with an average herbage height of $6.6 \pm 0.7 \mathrm{~cm}$ (mean $\pm \mathrm{SD}$; measured 3 times/wk using an electronic rising plate meter; manufacturer: RPM F400, Farmworks Systems Ltd., Manawatu-Wanganui, New Zealand) and daily pasture allowances were as follows: wk 5 and $6: 24.2 \pm$ 2.2; wk 7 and 8: $23.8 \pm 4.3$; wk 9 and 10: $16.5 \pm 4.5 \mathrm{~kg}$ of $\mathrm{DM} /$ cow per d (estimated from undisturbed average grass growth using exclosure cages compared with a reference area next to the cage; described in detail in Schären et al. (2016); adverse weather conditions in wk 7 and 8 caused low herbage allowance in wk 9 and 10). The cows were milked 2 times per day at 0530 and $1500 \mathrm{~h}$. The TMR was fed daily at approximately $1100 \mathrm{~h}$, and individual DMI of TMR was continuously recorded (electronic weighing troughs, manufacturer: Insentec, B.V., Marknesse, the Netherlands). In the PG, individual DMI of pasture was estimated in wk 7 and 9 using the n-alkane method (described in detail in Schären et al. (2016). Body weight was measured twice daily after milking.

\section{Rumen $\mathrm{pH}$ and Fluid Composition}

Rumen fluid samples were collected once per week after morning milking. To prevent substantial grazing activity before sampling cows of the PG were rounded up for milking just before sunrise (Taweel et al., 2004; Abrahamse et al., 2009). To collect rumen fluid from the medial site, the rumen mat content from the first $10 \mathrm{~cm}$ below the aperture of the rumen fistula was collected and pressed through a cheesecloth. Rumen fluid from the ventral site of the rumen was collected using a manual pump. Immediately after collection, $\mathrm{pH}$ was measured using a glass electrode (model: $\mathrm{pH}$ 525; WTW, Weilheim, Germany) and samples were cooled to $4^{\circ} \mathrm{C}$ until further processing approximately 1 to $2 \mathrm{~h}$ after sample collection. Volatile fatty acids were determined as described in Geissler et al. (1976), and $\mathrm{NH}_{3}-\mathrm{N}$ was determined using steam distillation according to the Kjeldahl method [DIN38406-E5-2, Anonymous (1998)]. For determination of LPS concentration, rumen fluid samples were centrifuged at $10,000 \times g$ at $6^{\circ} \mathrm{C}$ in pyrogen-free tubes for $30 \mathrm{~min}$. Thereafter, supernatants were passed through a 0.22 $\mu \mathrm{m}$ filter, heated for $30 \mathrm{~min}$ at $100^{\circ} \mathrm{C}$, and stored at $-20^{\circ} \mathrm{C}$ pending further analysis. Prior to analysis, supernatants were diluted with endotoxin-free water at approximately 1:32,000 vol/vol. Lipopolysaccharide concentrations were measured spectrophotometrically at $405 \mathrm{~nm}$ using the Limulus amoebocyte lysate assay (Kinetic-QCL, Lonza, Walkersville, MD; following the manufacturer's instructions) and a microplate reader with incubation chamber (Infinite M200, Tecan Group Ltd., Männedorf, Switzerland) and evaluated using the Magellan Data Analysis Software (Tecan Group Ltd.; Gozho et al., 2005).

Rumen content $\mathrm{pH}$ was continuously measured in the ventral rumen sac using a continuous ruminal $\mathrm{pH}$ measuring device in wk 1 to 10 in the PG and in wk 3 to 10 in the CG (Lethbridge Research Centre Ruminal pH Measurement System, Dascor, Escondido, CA; Penner et al. 2006). No continuous rumen $\mathrm{pH}$ data were collected in wk 1 and 2 in the CG due to technical issues at the time. Before and after each period the system was calibrated in buffer solutions $(\mathrm{pH} 4$ and 7$)$ at $39^{\circ} \mathrm{C}$. Ruminal content $\mathrm{pH}$ was recorded every minute and measured of each cow between 1 and 4 consecutive 24-h periods each week $(2.68 \pm 0.99$; mean $\pm \mathrm{SD})$. For each 24-h interval, a logistic curve was fitted (AlZahal et al., 2007) using PROC NLMIXED in SAS 9.3 (2011, SAS Institute Inc., Cary, NC) and the variables $\beta_{0}$ (the slope of the logistic curve at the inflection point, illustrating the variation in rumen $\mathrm{pH}$ over the assessed 24 -h interval), $\beta_{1}$ (describing the inflection point of the curve, representing the average $\mathrm{pH}$ of the assessed $24-\mathrm{h}$ period), and time $\mathrm{pH}<5.6$ and $\mathrm{pH}<5.8(\mathrm{~min} / \mathrm{d})$ were assessed as described in Colman et al. (2012). To evaluate a possible increased risk for SARA, a threshold of $314 \mathrm{~min}$ at $\mathrm{pH}<5.8 / \mathrm{d}$ and average $\mathrm{pH}$ lower than 6.16 was chosen (Zebeli et al., 2008). To allow a representative interpretation, the SARA risk was evaluated on the basis of least squares means on a group level and based on a scoring system on an individual basis. The score per group and week was calculated as score = [sum of (number of positive SARA observations per animal in week $i$ /total number of observations per animal in week $i$ )]/total number of animals assessed in week $i$. This approach was chosen because the amount of measurements and assessed animals differed between weeks. Animals were not exposed to SARA challenges before this trial. 


\section{Rumen Content}

In wk 1,5 , and 10, the rumen of each cow was evacuated by hand and total rumen content was separated into fluid and solid content using a self-made sieve with a 10-mm aperture (2-3 cows per day between 0730 and $1430 \mathrm{~h}$; all cows within $5 \mathrm{~d}$ within particular week). Samples were collected of the solid and liquid content and stored at $-20^{\circ} \mathrm{C}$ pending analyses. For each sample, the DM content was assessed to determine the total rumen DM and non-DM quantity. Both fractions were weighed separately, combined again thereafter, and kept in insulated barrels to prevent cooling.

\section{Rumen Papillae Collection}

After evacuation, the rumen was washed twice with $10 \mathrm{~L}$ of water $\left(39^{\circ} \mathrm{C}\right)$ and the remaining fluid was removed using an industrial vacuum cleaner. Thereafter, papillae were collected at 3 different sites in the rumen (saccus cecus caudodorsalis, saccus ventralis, and saccus cecus caudoventralis; always approximately $5 \mathrm{~cm}$ adjacent to the pila coronaria dorsalis or pila coronaria ventralis, respectively, at the most ventral site of the respective location) using a biopsy forceps (Lloyd-Davis biopsy forceps $35 \mathrm{~cm}$, Zepf Instruments, Tuttlingen, Germany). Papillae samples were immediately washed in $0.9 \% \mathrm{NaCl}$ and stored in $4 \%$ formaldehyde. Per location, $14.6 \pm 4.5$ (mean $\pm \mathrm{SD}$ ) intact papillae were collected. Subsequently, the papillae were photographed and the surface area (one side) was determined using the CellProfiler (Broad Institute, Cambridge, MA) software package. Thereafter, the rumen papillae were histopathologically examined for the presence of inflammation. To evaluate the samples representatively, we grouped the samples into either "absence of lesions" and "presence of lesions" for statistical analysis and graphical illustration.

\section{VFA Absorption Test}

Subsequent to the papillae collection, a VFA absorption test (VFA-AT) was performed as described by Dijkstra et al. (1993). A total of $36.5 \pm 0.4 \mathrm{~L}$ of a VFA buffer solution $\left(\mathrm{pH} 5.0 \pm 0.1 ; 400 \mathrm{mOsm} / \mathrm{L} ; 39^{\circ} \mathrm{C}\right)$ was prepared based on McDougall's buffer (Dijkstra et al., 1993), containing additionally $170 \mathrm{~m} M$ VFA $(60 \%$ acetic, $25 \%$ propionic, $15 \%$ butyric acid) and a marker $($ Co-EDTA, $0.07 \mathrm{~g} / \mathrm{L})$. The rumen was washed with 5 $\mathrm{L}$ of the buffer solution and the remaining fluid was removed using an industrial vacuum cleaner. Thereafter, $31.5 \mathrm{~L}$ of the buffer solution was introduced and a buffer solution sample was collected. After $60 \mathrm{~min}$ of in- cubation, another buffer solution sample was collected and the buffer solution was completely recovered and weighed. The $\mathrm{pH}$ and liquid volume were measured and the samples were stored at $-20^{\circ} \mathrm{C}$. During the VFA-AT, the $\mathrm{pH}$ of the buffer solution was assessed manually every 15 min from a $100-\mathrm{mL}$ sample, which was reintroduced into the rumen immediately after measuring. In wk 10, an indwelling and recording $\mathrm{pH}$ probe (inPro 3100/120/Pt100 combination $\mathrm{pH}$ electrode, Mettler Toledo, Giessen, Germany; mobile pH recording device PCE-228, PCE Deutschland GmbH, Meschede, Germany) was used to measure the buffer solution $\mathrm{pH}$ continuously during the incubation period in 9 animals $(\mathrm{n}=5 \mathrm{CG} ; \mathrm{n}=4 \mathrm{PG}$, data of one animal were lost due to technical issues). Finally, the rumen content was reintroduced. Buffer solution VFA concentrations were determined as described in Geissler et al. (1976). Buffer solution cobalt concentrations were measured using inductively coupled plasma optical emission spectrometry (Quantima, GBC Scientific Equipment Pty Ltd., Victoria, Australia). The water inflow, fractional liquid passage rate (FLPR), and fractional absorption rates (FAR) of acetic, propionic, and butyric acids were calculated according to Dijkstra et al. (1993).

\section{Statistical Analysis}

If variables were recorded more than once a week, means were calculated per cow and week before statistical evaluation. To obtain a normal distribution, LPS concentrations were logarithmically transformed before statistical analysis. To analyze repeated measurements, PROC MIXED in SAS Enterprise Guide 6.1 (SAS Institute Inc.) was implemented using the following model (Littell et al., 2006):

$$
\mathrm{Y}_{\mathrm{ijkl}}=\mu+\mathrm{G}_{\mathrm{i}}+\mathrm{W}_{\mathrm{k}}+(\mathrm{G} \times \mathrm{W})_{\mathrm{ik}}+\mathrm{C}_{\mathrm{j}}+\varepsilon_{\mathrm{ijk}},
$$

and in case of multiple sampling sites the model was extended to

$$
\begin{gathered}
\mathrm{Y}_{\mathrm{ijkl}}=\mu+\mathrm{G}_{\mathrm{i}}+\mathrm{W}_{\mathrm{k}}+\mathrm{S}_{\mathrm{l}}+(\mathrm{G} \times \mathrm{S})_{\mathrm{il}}+(\mathrm{G} \times \mathrm{W})_{\mathrm{ik}} \\
+(\mathrm{W} \times \mathrm{S})_{\mathrm{kl}}+(\mathrm{G} \times \mathrm{W} \times \mathrm{S})_{\mathrm{ikl}}+\mathrm{C}_{\mathrm{j}}+\mathrm{W}(\mathrm{C})_{\mathrm{jk}}+\varepsilon_{\mathrm{ijkl}},
\end{gathered}
$$

where $G_{i}=$ treatment group $(i=\mathrm{PG}, \mathrm{CG}), W_{k}=$ sampling week $(k=1, \ldots, 10), S_{l}=$ sampling site $(l=$ medial, ventral for $\mathrm{pH}, \mathrm{VFA}, \mathrm{NH}_{3}-\mathrm{N}$, LPS; $l=$ saccus cecus caudodorsalis, saccus ventralis, saccus cecus caudoventralis for biopsies $),(G \times W)_{i k}=$ fixed interaction, $C_{j}=\operatorname{cow}(j=1, \ldots, 10), W(C)_{j k}=$ random effects of sampling week within cows, and $\varepsilon_{i j k}$ and $\varepsilon_{i j k l}=$ error. 
A REML with the cows as experimental units was used. Week, diet group, sampling site within the rumen (where applicable), and their interaction were defined as fixed factors. A REPEATED statement was included to account for individual variation of the cows. Best fitting covariance structures were tested using the Akaike information criterion for a finite sample size (AICC). For the performance data of the animals, first order autoregressive was chosen, and for all other data compound symmetry covariance structure was chosen. In case of multiple sampling sites, the site was nested within the cow and a RANDOM statement was included for cow and cow $\times$ week interaction to account for pseudo-replication. Significant effects at different points in time were further evaluated by multiple $t$-test (procedure PDIFF) and results are presented as least squares means with pooled standard error of means. Histopathological scores of rumen papillae were arranged in contingency tables and analyzed by using Fisher's exact tests (PROC FREQ) in SAS Enterprise Guide 6.1. Correlation coefficients between different parameters were estimated using Statistica 12.0 (2014, StatSoft Inc., Tulsa, OK). Results were considered significant at $P<0.05$ and a trend declared at $0.05<P$ $<0.10$.

\section{RESULTS}

\section{Ration Composition and Weather Data}

The chemical composition of the different rations and weather data are presented in detail in Schären et al. (2016). Briefly, the average chemical composition of the TMR of the CG and the PG was DM content: $330 \pm 12$ $\mathrm{g} / \mathrm{kg}, \mathrm{CP}: 128 \pm 4 \mathrm{~g} / \mathrm{kg}$ of $\mathrm{DM}, \mathrm{NE}_{\mathrm{L}}: 6.8 \pm 0.1 \mathrm{MJ} / \mathrm{kg}$ of DM, starch: $262 \pm 3 \mathrm{~g} / \mathrm{kg}$ of DM, CF: $204 \pm 4 \mathrm{~g} / \mathrm{kg}$ of $\mathrm{DM}, \mathrm{NDF}_{\mathrm{om}}: 394 \pm 9 \mathrm{~g} / \mathrm{kg}$ of DM and $\mathrm{ADF}_{\mathrm{om}}: 226$ $\pm 5 \mathrm{~g} / \mathrm{kg}$ of DM (mean $\pm \mathrm{SD}$; NDF and ADF were expressed without residual ash and are therefore referred to as $\mathbf{N D F}_{\text {om }}$ and $\mathbf{A D F}$ om ). Chemical composition of the pasture was assessed weekly: DM content: $183 \pm$ $14 \mathrm{~g} / \mathrm{kg}, \mathrm{CP}: 193 \pm 21 \mathrm{~g} / \mathrm{kg}$ of DM, sugar: $113 \pm 32$ $\mathrm{g} / \mathrm{kg}$ of DM, CF: $216 \pm 8 \mathrm{~g} / \mathrm{kg}$ of $\mathrm{DM}, \mathrm{NDF}_{\text {om }}: 525$ $\pm 40 \mathrm{~g} / \mathrm{kg}$ of DM, and $\mathrm{ADF}_{\mathrm{om}}: 260 \pm 16 \mathrm{~g} / \mathrm{kg}$ of $\mathrm{DM}$ (mean $\pm \mathrm{SD}$ ). In wk 7 and 10, the highest sugar (174 and $148 \mathrm{~g} / \mathrm{kg}$, respectively) and lowest CP contents (159 and $167 \mathrm{~g} / \mathrm{kg}$, respectively) were observed. Additionally, pasture $\mathrm{NE}_{\mathrm{L}}$ contents were assessed in wk $7(6.7 \mathrm{MJ} / \mathrm{kg}$ of DM) and wk 9 (6.6 MJ/kg of DM). The average daily temperature-humidity index (THI) averaged $57.9 \pm 5.5$ outdoors and indoors was generally $5.1 \pm 0.8$ (mean \pm SD) units higher. Periods of mild heat were measured in wk 5 and between wk 7 and 8 with average daily THI between 65 and 70 outdoors and 65 and 75 indoors.

\section{Animal Performance}

For the presentation of the results the terms group, time, and location were chosen to describe the effect of diet group, week, and sampling location within the rumen, respectively. Milk production and BW changes in the fistulated cows (Table 1) were similar to those in the 60 cows described in Schären et al. (2016). For all variables, except BCS, a group $\times$ time interaction was observed. Dry matter intake from TMR decreased in the PG as soon as animals had part-time access to pasture. In the PG, DMI of pasture and concentrate differed significantly in wk 7 , but not in wk 9 , from that of TMR in the CG. However, this difference was significant in wk 9 in all 60 animals. Between wk 1 and 6 , milk yield in $\mathrm{PG}$ decreased by $4.3 \mathrm{~kg} / \mathrm{d}$ followed by stabilization until the end of the trial. In the CG, milk yield decreased more steadily over the course of the trial. A tendency for a higher milk yield in the CG was observed in wk 5 . In the PG, milk protein content slightly decreased from wk 4 to 5 and wk 6 , followed by an increase until wk 9 leading to a tendency for a higher milk protein content compared with the CG in wk 8 and 9. Within the CG, milk protein content marginally increased between wk 1 and 4 . In the PG, milk fat content decreased as soon as the cows were on a full grazing ration. Milk fat content in the CG compared with PG was higher in wk 5, 9 (tendency only), and 10. Milk urea concentration in PG increased from wk 4 onward, whereas no considerable alterations were observed in the CG. Milk urea concentrations were higher in the PG in wk 4 to 10 (except for wk 7). Body weight decreased in the PG between wk 1 and 6 by 32 $\mathrm{kg}$ and continuously increased thereafter until wk 10 to initial status. In the CG, an initial increase of BW by $18 \mathrm{~kg}$ until wk 4 followed by a decrease until wk 10 to initial status was observed. A higher BW was observed in the CG compared with the PG between wk 4 to 7 . The decrease of $0.8 \mathrm{BCS}$ points in the $\mathrm{PG}$ over the course of, and 0.3 BCS points in the CG during the last weeks of the trial (in all 60 cows) was only numerically reflected in the fistulated cows (no significant group $\times$ time interaction). However, a significant group effect was found for BCS within the fistulated animals; the BCS in PG already was lower than in CG at the beginning of the trial.

\section{Rumen $\mathrm{pH}$ and Fluid Composition}

$\boldsymbol{p H}$-Sensor Data. Four main variables $\left[\beta_{0}, \beta_{1}\right.$, and time $\mathrm{pH}<5.8$ and $<5.6(\mathrm{~min} / \mathrm{d})]$ describing the development of rumen $\mathrm{pH}$ throughout the trial in the $\mathrm{PG}$ and CG are illustrated in Figure 1A. For $\beta_{1}$, representing the average $\mathrm{pH}$ of the assessed 24 -h period, a group 
Table 1. Effect of a ration change from TMR to pasture on animal performance ${ }^{1}$

The

\begin{tabular}{|c|c|c|c|c|c|c|c|c|c|c|c|c|c|c|c|}
\hline \multirow[b]{2}{*}{ Variable $^{2}$} & \multirow[b]{2}{*}{ Group $^{3}$} & \multicolumn{10}{|c|}{ Week } & \multirow[b]{2}{*}{ PSEM $^{4}$} & \multicolumn{3}{|c|}{$P$-value } \\
\hline & & 1 & 2 & 3 & 4 & 5 & 6 & 7 & 8 & 9 & 10 & & G & $\mathrm{T}$ & $\mathrm{G} \times \mathrm{T}$ \\
\hline \multirow[t]{2}{*}{ DMI $(\mathrm{kg} / \mathrm{d})$} & CG & $16.8^{\mathrm{d}-\mathrm{f}}$ & $17.4^{* * a-f}$ & $16.9^{* * \mathrm{~d}-\mathrm{f}}$ & $18.3^{* * a-\mathrm{e}}$ & $17.2^{\mathrm{b}-\mathrm{f}}$ & $17.1^{\mathrm{c}-\mathrm{f}}$ & $18.2^{* * a-d}$ & $16.7^{\mathrm{ef}}$ & $17.4^{\mathrm{a}-\mathrm{e}}$ & $15.6^{\mathrm{f}}$ & 0.9 & 0.004 & $<0.001$ & $<0.001$ \\
\hline & $\mathrm{PG}$ & $17.3^{\mathrm{a}}$ & $13.1^{\mathrm{b}}$ & $9.7^{\mathrm{d}}$ & $10.8^{\mathrm{c}}$ & - & 2.8 & $13.7^{\mathrm{b}}$ & & $16.2^{\mathrm{a}}$ & & & & & \\
\hline \multirow{2}{*}{$\begin{array}{l}\text { Milk yield } \\
(\mathrm{kg} / \mathrm{d})\end{array}$} & CG & $23.9^{\mathrm{ab}}$ & $24.4^{\mathrm{a}}$ & $23.1^{\mathrm{b}}$ & $22.4^{\mathrm{b}}$ & $22.8 t^{\mathrm{b}}$ & $22.0^{\mathrm{b}}$ & $21.9^{\mathrm{b}}$ & $19.8^{\mathrm{c}}$ & $19.4^{\mathrm{c}}$ & $18.3^{\mathrm{d}}$ & 1.4 & 0.449 & $<0.001$ & 0.023 \\
\hline & $\mathrm{PG}$ & $23.1^{\mathrm{a}}$ & $23.0^{\mathrm{a}}$ & $21.6^{\mathrm{b}}$ & $20.5^{\mathrm{ce}}$ & $19.1^{\mathrm{de}}$ & $18.8^{\mathrm{de}}$ & $19.3^{\mathrm{c}-\mathrm{e}}$ & $18.8^{\mathrm{e}}$ & $20.1^{\text {cd }}$ & $19.4^{c-e}$ & & & & \\
\hline \multirow{2}{*}{$\begin{array}{l}\text { Milk protein } \\
\text { content }(\%)\end{array}$} & $\mathrm{CG}$ & $2.99^{\mathrm{e}}$ & $3.02^{\mathrm{de}}$ & $3.03^{\mathrm{be}}$ & $3.14^{\mathrm{a}}$ & $3.02^{\mathrm{c} e}$ & $3.05^{\mathrm{a}-\mathrm{e}}$ & $3.10^{\mathrm{a}-\mathrm{e}}$ & $3.06 t^{\mathrm{a}-\mathrm{e}}$ & $3.09 \mathrm{t}^{\mathrm{a}-\mathrm{e}}$ & $3.15^{\mathrm{a} e \mathrm{e}}$ & 0.08 & 0.621 & $<0.001$ & 0.002 \\
\hline & $\mathrm{PG}$ & $3.05^{\mathrm{b}-\mathrm{d}}$ & $3.08^{b-d}$ & $3.09^{\mathrm{b}-\mathrm{d}}$ & $3.17^{\mathrm{ab}}$ & $2.98^{\mathrm{cd}}$ & $2.97^{\mathrm{d}}$ & $3.05^{\mathrm{b}-\mathrm{d}}$ & $3.28^{\mathrm{a}}$ & $3.28^{\mathrm{a}}$ & $3.13^{\mathrm{bc}}$ & & & & \\
\hline \multirow{2}{*}{$\begin{array}{l}\text { Milk fat } \\
\text { content }(\%)\end{array}$} & CG & 4.38 & 4.35 & 4.42 & 4.33 & $4.22 *$ & 4.37 & 4.47 & 4.26 & $4.51 \dagger$ & $4.66^{* *}$ & 0.26 & 0.100 & 0.001 & 0.020 \\
\hline & $\mathrm{PG}$ & $4.13^{\mathrm{a}-\mathrm{c}}$ & $4.03^{\mathrm{a}-\mathrm{c}}$ & $4.33^{\mathrm{ab}}$ & $4.49^{\mathrm{a}}$ & $3.41^{\mathrm{d}}$ & $4.04^{\mathrm{a}-\mathrm{c}}$ & $3.92^{\mathrm{bc}}$ & $3.67^{\mathrm{cd}}$ & $3.84^{\mathrm{b}-\mathrm{d}}$ & $3.52^{\mathrm{cd}}$ & & & & \\
\hline \multirow{4}{*}{$\begin{array}{l}\text { Milk urea } \\
(\mathrm{ppm}) \\
\text { BW (kg) }\end{array}$} & CG & $141^{\mathrm{bc}}$ & $169^{\mathrm{a}}$ & $129^{\mathrm{bc}}$ & $125^{* * \mathrm{bc}}$ & $124^{* * c}$ & $151^{* a \mathrm{ab}}$ & $141^{\mathrm{abc}}$ & $129^{* * \mathrm{bc}}$ & $132^{* * b c}$ & $130^{* * \mathrm{bc}}$ & 15 & $<0.001$ & $<0.001$ & $<0.001$ \\
\hline & $\mathrm{PG}$ & $159^{\mathrm{de}}$ & $163^{\mathrm{de}}$ & $164^{\mathrm{de}}$ & $197^{\mathrm{c}}$ & $236^{\mathrm{b}}$ & $197^{\text {cd }}$ & $144^{\mathrm{e}}$ & $373^{\mathrm{a}}$ & $244^{\mathrm{b}}$ & $191^{\mathrm{cd}}$ & & & & \\
\hline & $\mathrm{CG}$ & $655^{\mathrm{c}}$ & $662^{\mathrm{b}}$ & $666^{\mathrm{ab}}$ & $673^{* a}$ & $667^{* \mathrm{a}-\mathrm{c}}$ & $663^{* \mathrm{bc}}$ & $665^{* a-c}$ & $659^{\mathrm{bc}}$ & $657^{\mathrm{bc}}$ & $655^{\mathrm{bc}}$ & 23 & 0.085 & 0.004 & $<0.001$ \\
\hline & PG & $614^{\mathrm{abd}}$ & $604^{c-e}$ & $598^{\mathrm{e}}$ & $599^{\mathrm{e}}$ & $585^{\mathrm{f}}$ & $582^{\mathrm{f}}$ & $585^{\mathrm{f}}$ & $602^{\mathrm{de}}$ & $608^{\mathrm{b}-\mathrm{e}}$ & $616^{\mathrm{ac}}$ & & & & \\
\hline \multirow{2}{*}{$\begin{array}{l}\mathrm{BCS} \\
\text { (scale 1-5) }\end{array}$} & CG & 3.7 & \multicolumn{2}{|c|}{3.5} & \multicolumn{2}{|c|}{3.5} & \multicolumn{2}{|c|}{3.5} & \multicolumn{2}{|c|}{3.4} & 3.2 & 0.3 & 0.023 & 0.001 & 0.685 \\
\hline & PG & 2.7 & \multicolumn{2}{|c|}{2.4} & \multicolumn{2}{|c|}{2.5} & \multicolumn{2}{|c|}{2.3} & \multicolumn{2}{|r|}{2.2} & 1.9 & & & & \\
\hline
\end{tabular}

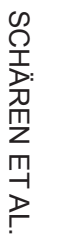

${ }^{\mathrm{a}-\mathrm{f}}$ Values within ration group in a row with different superscript letters differ $(P<0.05)$.

${ }^{1}$ Fistulated animals only; Materials and Methods described in Schären et al. (2016).

${ }^{2}$ Dry matter intake: CG (wk 1-10) and PG (wk 1-4) DMI from TMR only, PG in wk 7 and 9 DMI from pasture (n-alkane method) plus concentrate (1.75 kg of DM/d); BCS was assessed at the beginning of each week in 14-d intervals and at the last day of wk 10; values presented as LSM.

${ }^{3} \mathrm{CG}=$ confinement group $(\mathrm{n}=5) ; \mathrm{PG}=$ pasture group $(\mathrm{n}=5)$; the CG stayed on a TMR-based ration during the entire trial, whereas the PG was slowly introduced to a pasturebased ration: wk 1: TMR; wk 2: TMR and $3 \mathrm{~h}$ pasture/d; wk 3 and 4: TMR and $12 \mathrm{~h}$ pasture/d; wk 5 to 10: pasture and $1.75 \mathrm{~kg}$ of DM concentrate/d.

${ }^{4} \mathrm{PSEM}=$ pooled standard error of the means; $\mathrm{G}=$ group, $\mathrm{T}=$ time.

$\dagger P<0.10 ;{ }^{*} P<0.05 ;{ }^{* *} P<0.01$; symbols indicate difference between groups within a particular week. 
$\times$ time interaction was observed. The PG exhibited a decrease between wk 2 and 10 (from 6.2 to 6.1), whereas in the $\mathrm{CG}$ a continuous increase during the course of the trial was observed (from 6.1 in wk 3 until 6.3 in wk 10). In wk $10, \beta_{1}$ was significantly lower in the PG compared with the CG. The variable $\beta_{0}$, illustrating the variation in rumen $\mathrm{pH}$ over the assessed 24 -h interval (the greater, the more constant), exhibited a time as well as group $\times$ time effect. In the PG, an increase was observed as soon as the animals were on a full-grazing ration in wk 5. Subsequently, a decrease in wk 8 to 10 occurred. In the CG, no considerable variations were observed except for an increase in wk 5 . In wk 6 and $7, \beta_{0}$ was higher in $\mathrm{PG}$ than in the CG. No significant time or group effect nor a group $\times$ time interaction was observed for the variable time $\mathrm{pH}<5.8(\mathrm{~min} / \mathrm{d})$. Time $\mathrm{pH}<5.6(\mathrm{~min} / \mathrm{d})$ did not exhibit a significant group or group $\times$ time effect. However, a significant time effect was observed due to an increase between wk 3 and 4 , subsequent decrease until wk 7 , and increase again until wk 10 in both groups.

No increased risk for SARA was observed on group level at any time during the trial in both groups. On an individual basis, the average score was $0.11 \pm 0.08$ for the $\mathrm{CG}$ and $0.11 \pm 0.15$ for the $\mathrm{PG}$ in wk 3 to 10 (means $\pm \mathrm{SD}$; no wk 1 and 2 due to technical problems with measurements in $\mathrm{CG}$ at the time). The highest score for CG was 0.30 in wk 4 and lowest in wk 6 (zero). In the PG the highest scores were observed in wk 1 (0.40), 9 (0.20), and $10(0.40)$ and the lowest in wk 2 and wk 6 to 8 (zero).

$\boldsymbol{p H}$-Manual. For the weekly manual $\mathrm{pH}$ measurements, a time and location effect, as well as a group $\times$ time, group $\times$ location, time $\times$ location, and group $\times$ time $\times$ location interaction were observed (Figure 1B). The $\mathrm{pH}$ of rumen fluid samples collected in the ventral part of the rumen was generally $0.52 \pm 0.04$ higher compared with those collected in the medial part. In wk 1 and 3 , a higher medial $\mathrm{pH}$ was observed in $\mathrm{PG}$ than $C G$, whereas during the full grazing period medial $\mathrm{pH}$ was higher in $\mathrm{CG}$ than in $\mathrm{PG}$ in wk 6,8 , and 9. A correlation between $\beta_{1}$ and manually assessed $\mathrm{pH}$ in the medial and ventral part of the rumen was found (medial: $\mathrm{r}=0.40, P<0.001$; ventral: $\mathrm{r}=0.30 ; P=0.004$ ).

VFA Concentrations and Molar Proportions. A group and time effect as well as a group $\times$ time interaction was observed for total VFA concentrations due to a significant increase between wk 7 to 10 in the PG from 95.2 to $100.2 \mathrm{mmol} / \mathrm{L}(P<0.05)$ and concurrent decrease in the CG between the first and second half of the trial (Figure 1C; from $101.2 \pm 2.4$ in wk $1-4$ to $91.6 \pm 3.4 \mathrm{mmol} / \mathrm{L}$ in wk $5-10$; mean $\pm \mathrm{SD} ; P<0.05)$. A significant difference between groups was present in wk 3 (CG higher than PG), and wk 6, 8, 9, and 10
(PG higher than CG). Medial and ventral total VFA concentrations correlated with corresponding manually assessed medial and ventral $\mathrm{pH}$ (medial: $\mathrm{r}=-0.78, P$ $<0.001$; ventral: $\mathrm{r}=-0.65, P<0.001)$ as well as $\beta_{1}$ (medial: $\mathrm{r}=-0.60, P=0.009$; ventral: $\mathrm{r}=-0.41 ; P$ $=0.094)$.

The acetate/propionate $(\mathbf{C 2} / \mathbf{C 3})$ ratio and the molar proportions of VFA are illustrated in Table 2. The $\mathrm{C} 2 / \mathrm{C} 3$ ratio decreased in the $\mathrm{PG}$ between wk 1 and 3 (from 3.90 to $3.23 ; P<0.001$ ), increased thereafter until wk 6 (to $3.54 ; P=0.082$ ), followed by a decrease until wk 9 (to $3.03 ; P=0.005$ ). In the $\mathrm{CG}$, a slight increase was observed over the course of the trial (from 3.21 in wk 2 to 3.58 in wk $9 ; P=0.037$ ), contributing to a significant group $\times$ time effect. A difference between groups was observed in wk 1 and 9 (wk 1 higher in the PG, wk 10 higher in the CG).

Molar acetate proportions (C2\%) exhibited a time and location effect as well as a group $\times$ time and group $\times$ time $\times$ location interaction. In the $\mathrm{CG}$, at both locations an initial increase in the first half of the trial (until wk 6), followed by a decrease at the ventral location in the second half was observed (no alterations at medial site). Medial C2\% were higher compared with ventral from wk 4 on in the CG [tendency for difference in wk $4(P=0.062)$, significant differences in wk 6 to $10(P<0.05)]$. In the PG, C2\% decreased continuously over the course of the trial.

Molar propionate proportions (C3\%) only exhibited a location effect due to generally higher $\mathrm{C} 3 \%$ at the ventral compared with the medial sampling site (20.0 vs. $19.7 \%, P=0.012)$.

Molar butyrate proportions (C4\%) continuously increased in both groups over the course of the trial (from 12.5 to $13.7 \%$ in the $\mathrm{CG}$ and from 11.3 to $13.5 \%$ in the PG between wk 1 and 10, $P<0.05$ ), except for a decrease and subsequent increase in wk 6 and 9 in the $\mathrm{CG}$, leading to a group $\times$ time interaction. $\mathrm{A}$ difference between groups was observed in wk 1 and 3 (CG higher), and wk 9 (PG higher). Medial C4\% were generally lower compared with ventral $\mathrm{C} 4 \%$ (12.3 vs. $13.0 \%, P<0.001)$.

Molar isovalerate proportions (iC5\%) exhibited a group and time effect as well as a group $\times$ time interaction. In the CG, iC5\% decreased over the course of the trial (from $1.8 \%$ in wk 1 to $1.1 \%$ in wk $10, P<0.001$ ). In the PG, an initial decrease until wk 7 (from $1.4 \%$ in wk 1 to $0.5 \%, P<0.001)$ and subsequent increase until wk $10(0.8 \%, P=0.016)$ was observed. The CG exhibited higher iC5\% than the PG between wk 3 to 9 .

Ventral molar valerate proportions (C5\%) were not altered significantly over the course of the trial $(0.40 \%)$, whereas medial $\mathrm{C} 5 \%$ exhibited a decrease until wk 6 (from 0.50 to $0.22 \%, P=0.002$ ), followed by a subse- 
A.

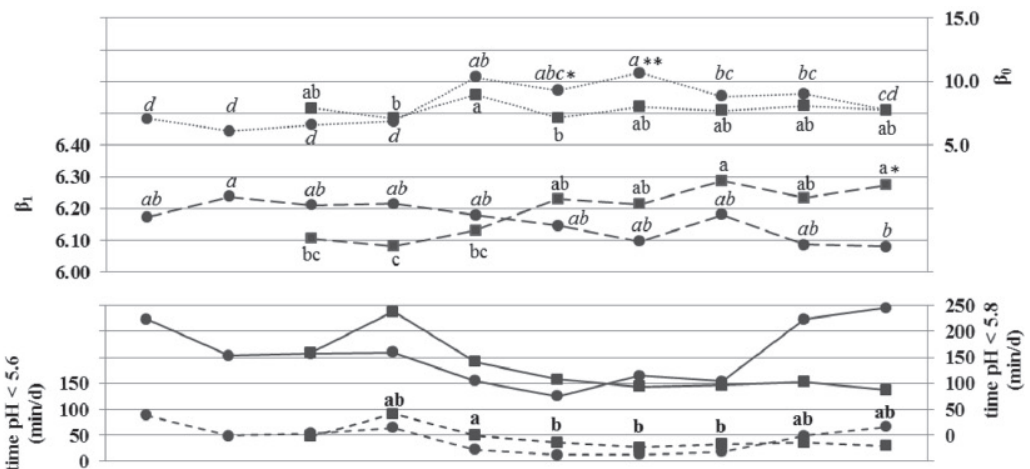

B.

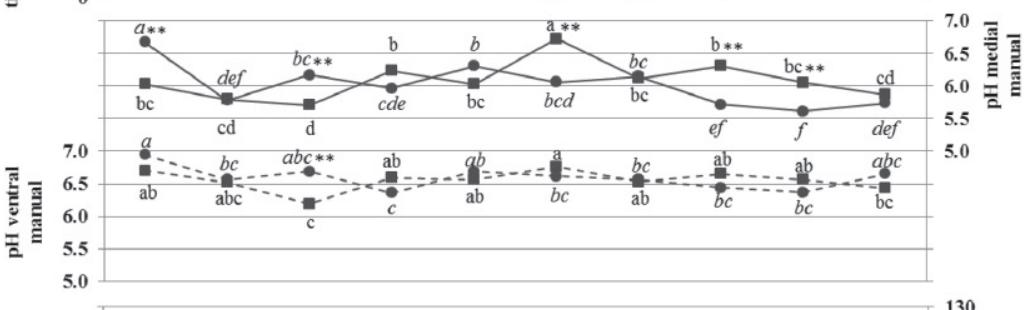

C.

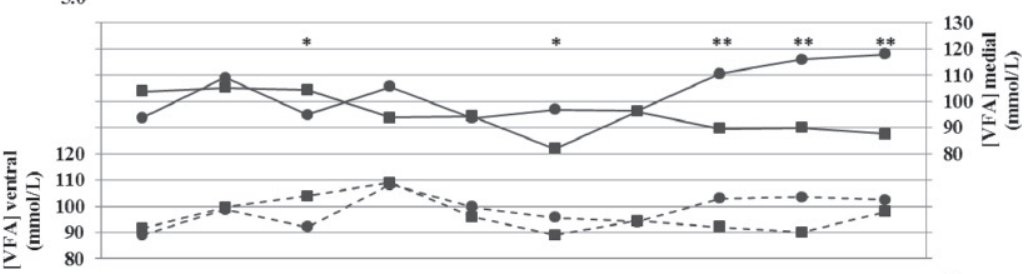

D.

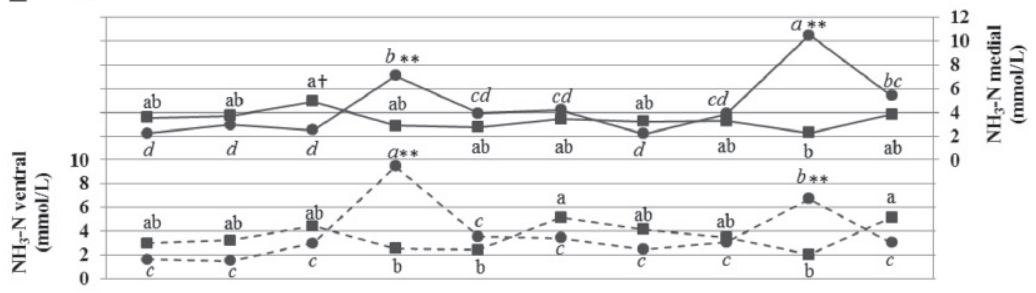

E.

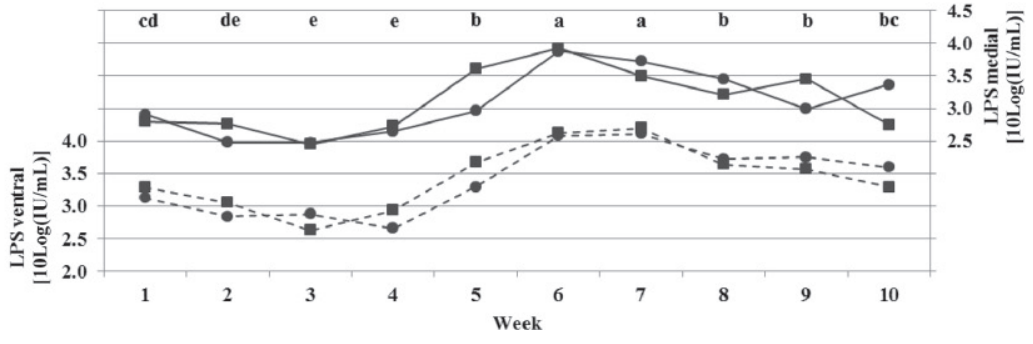

Figure 1. Effect of ration change from TMR to pasture on rumen fermentation variables measured weekly during the trial. $\mathbf{\square}=$ confinement group (CG); $\bullet$ pasture group (PG). (A) pH-sensor. Light dashed line $=\beta_{0}$, the slope of the logistic curve at the inflection point, illustrating the variation in rumen $\mathrm{pH}$ over the assessed 24-h interval [the greater, the more constant; pooled SEM $(\mathrm{PSEM})=0.7$ ]; long dashed line $=\beta_{1}$, inflection point of the logistic curve, representing the average $\mathrm{pH}$ of the assessed 24 -h period $(\mathrm{PSEM}=0.07)$; solid line $=$ time $\mathrm{pH}<5.8(\mathrm{~min} / \mathrm{d}$; PSEM $=75)$; short dashed line $=$ time $\mathrm{pH}<5.6(\mathrm{~min} / \mathrm{d} ; \mathrm{PSEM}=22)$. Significance: $\beta_{0}:$ group $(\mathrm{G}): P=0.242$, time $(\mathrm{T}): P<0.001, \mathrm{G} \times \mathrm{T}: P=$ 0.027; $\beta_{1}$ : group: $P=0.537$, time: $P<0.634, \mathrm{G} \times \mathrm{T}: P=0.008$; time $\mathrm{pH}<5.8$ : group: $P=0.756$, time: $P=0.258, \mathrm{G} \times \mathrm{T}: P=0.208$; time $\mathrm{pH}$ <5.6: group: $P=0.760$, time: $P=0.012, \mathrm{G} \times \mathrm{T}: P=0.595$. Logger data in wk 1 and 2 in $\mathrm{CG}$ are missing due to technical issues at the time. (B) $\mathrm{pH}-$ manual. Dashed line $=$ ventral part of the rumen; solid line $=$ medial part of the rumen $(\mathrm{PSEM}=0.12)$. Significance: group: 0.818 , time: $P<0.001$, location (L): $P<0.001, \mathrm{G} \times \mathrm{T}: P<0.001 ; \mathrm{G} \times \mathrm{L}: P=0.037 ; \mathrm{T} \times \mathrm{L}: P=0.010, \mathrm{G} \times \mathrm{T} \times \mathrm{L}: P=0.030$. (C) Total VFA concentration. Dashed line $=$ ventral part of the rumen; solid line $=$ medial part of the rumen $(\mathrm{PSEM}=5)$. Significance: group: $P=0.023$, time: $P=0.002$, location: $P=0.474, \mathrm{G} \times \mathrm{T}: P<0.001 ; \mathrm{G} \times \mathrm{L}: P=0.147 ; \mathrm{T} \times \mathrm{L}: P=0.050, \mathrm{G} \times \mathrm{T} \times \mathrm{L}: P=0.156$. (D) $\mathrm{NH}_{3}-\mathrm{N}$ concentration. Dashed line $=$ ventral; solid line $=$ medial $(\mathrm{PSEM}=1.9)$. Significance: group: $P=0.272$, time: $P=0.003$, location: $P=0.303, \mathrm{G} \times \mathrm{T}: P<0.001 ; \mathrm{G} \times \mathrm{L}: P=0.124$; $\mathrm{T} \times \mathrm{L}: P=0.011, \mathrm{G} \times \mathrm{T} \times \mathrm{L}: P=0.002$. (E) LPS concentration. Dashed line $=$ ventral; solid line $=$ medial $(\mathrm{PSEM}=0.14)$. Significance: group: $P$ $=0.700$, time: $P<0.001$, location: $P<0.001, \mathrm{G} \times \mathrm{T}: P=0.062 ; \mathrm{G} \times \mathrm{L}: P=0.973 ; \mathrm{T} \times \mathrm{L}: P=0.722, \mathrm{G} \times \mathrm{T} \times \mathrm{L}: P=0.414$. LSM; $=5$. Different letters indicate significant differences between groups in a particular week (within a particular location if applicable; $† P<0.10 ;{ }^{*} P<0.05 ; * * P$ $<0.01$ ). Letters indicate significant differences between weeks (within a particular group and location if applicable; $P<0.05$ ). The CG stayed on a TMR-based ration during the entire trial, whereas the PG was slowly introduced to a pasture-based ration: wk 1: TMR, wk 2: TMR and $3 \mathrm{~h}$ pasture/d, wk 3 and 4: TMR and $12 \mathrm{~h}$ pasture/d, wk 5 to 10: pasture and $1.75 \mathrm{~kg}$ of DM concentrate/d. 
Table 2. Effect of ration change from TMR to pasture on acetate/propionate ratio and VFA molar proportions in medial and ventral part of the rumen

\begin{tabular}{|c|c|c|c|c|c|c|c|c|c|c|c|c|c|c|c|c|c|c|c|}
\hline \multirow[b]{2}{*}{ Variable $^{1}$} & \multirow[b]{2}{*}{ Group $^{2}$} & \multicolumn{10}{|c|}{ Week } & \multirow[b]{2}{*}{$\mathrm{PSEM}^{3}$} & \multicolumn{7}{|c|}{$P$-values } \\
\hline & & 1 & 2 & 3 & 4 & 5 & 6 & 7 & 8 & 9 & 10 & & $\mathrm{G}$ & $\mathrm{T}$ & $\mathrm{L}$ & $\mathrm{G} \times \mathrm{T}$ & $\mathrm{G} \times \mathrm{L}$ & $\mathrm{T} \times \mathrm{L}$ & $\mathrm{G} \times \mathrm{T} \times \mathrm{L}$ \\
\hline \multirow{2}{*}{$\begin{array}{l}\mathrm{C} 2 / \mathrm{C} 3 \\
\text { medial }\end{array}$} & $\mathrm{CG}$ & $3.39^{*}$ & 3.28 & 3.31 & 3.28 & 3.39 & 3.46 & 3.63 & 3.47 & $3.66^{*}$ & 3.41 & \multirow[t]{4}{*}{0.18} & \multirow[t]{4}{*}{0.945} & \multirow[t]{4}{*}{0.048} & \multirow[t]{4}{*}{0.006} & \multirow[t]{4}{*}{0.011} & \multirow[t]{4}{*}{0.107} & \multirow[t]{4}{*}{0.903} & \multirow[t]{4}{*}{0.283} \\
\hline & PG & 3.93 & 3.49 & 3.23 & 3.40 & 3.40 & 3.63 & 3.33 & 3.33 & 3.03 & 3.21 & & & & & & & & \\
\hline \multirow{2}{*}{$\begin{array}{l}\mathrm{C} 2 / \mathrm{C} 3 \\
\text { ventral }\end{array}$} & $\mathrm{CG}$ & 3.39 & 3.15 & 3.19 & 3.21 & 3.31 & 3.35 & 3.43 & 3.32 & 3.50 & 3.10 & & & & & & & & \\
\hline & PG & 3.87 & 3.48 & 3.23 & 3.20 & 3.38 & 3.45 & 3.31 & 3.33 & 3.03 & 3.23 & & & & & & & & \\
\hline \multirow{2}{*}{$\begin{array}{l}\mathrm{C} 2 \% \\
\text { medial }\end{array}$} & $\mathrm{CG}$ & $65.6^{* * \mathrm{bc}}$ & $65.1^{\mathrm{c}}$ & $65.1 \dagger^{\mathrm{c}}$ & $65.6 \dagger^{\mathrm{bc}}$ & $66.0^{\mathrm{a}-\mathrm{c}}$ & $67.7^{\mathrm{a}}$ & $66.8^{\mathrm{a}-\mathrm{c}}$ & $65.8^{\mathrm{bc}}$ & $67.3^{* * a b}$ & $66.0^{\mathrm{a}-\mathrm{c}}$ & \multirow[t]{4}{*}{0.8} & \multirow[t]{4}{*}{0.317} & \multirow[t]{4}{*}{$<0.001$} & \multirow[t]{4}{*}{0.002} & \multirow[t]{4}{*}{$<0.001$} & \multirow[t]{4}{*}{0.062} & \multirow[t]{4}{*}{0.399} & \multirow[t]{4}{*}{0.043} \\
\hline & $\mathrm{PG}$ & $69.3^{\mathrm{a}}$ & $66.9^{\mathrm{b}-\mathrm{d}}$ & $66.9^{\mathrm{b}-\mathrm{d}}$ & $67.5^{\mathrm{a}-\mathrm{c}}$ & $67.3^{\mathrm{b}-\mathrm{d}}$ & $68.2^{\mathrm{ab}}$ & $65.7^{\mathrm{de}}$ & $65.8^{c-e}$ & $62.9^{\mathrm{f}}$ & $64.6^{\text {ef }}$ & & & & & & & & \\
\hline \multirow{2}{*}{$\begin{array}{l}\mathrm{C} 2 \% \\
\text { ventral }\end{array}$} & $\mathrm{CG}$ & $65.7^{* * a-c}$ & $64.5^{\mathrm{b}-\mathrm{d}}$ & $64.5^{\mathrm{cd}}$ & $64.3^{\mathrm{cd}}$ & $65.1^{\mathrm{a}^{-\mathrm{c}}}$ & $66.4^{\mathrm{a}}$ & $65.3^{\mathrm{a}-\mathrm{c}}$ & $64.3^{\mathrm{cd}}$ & $66.3^{* \mathrm{ab}}$ & $63.0 \dagger^{\mathrm{d}}$ & & & & & & & & \\
\hline & $\mathrm{PG}$ & $68.9^{\mathrm{a}}$ & $66.2^{\mathrm{bc}}$ & $66.4^{\mathrm{bc}}$ & $65.7^{\mathrm{bc}}$ & $66.5^{\mathrm{bc}}$ & $67.2^{\mathrm{ab}}$ & $65.6^{\mathrm{b}-\mathrm{d}}$ & $66.0^{\mathrm{bc}}$ & $63.8^{\mathrm{d}}$ & $65.2^{\mathrm{cd}}$ & & & & & & & & \\
\hline C3\% & CG & 19.5 & 20.5 & 19.8 & 20.4 & 19.7 & 19.7 & 18.5 & 19.1 & 18.7 & 19.5 & \multirow[t]{4}{*}{0.9} & 0.969 & 0.221 & 0.012 & 0.098 & 0.133 & 0.811 & 0.298 \\
\hline medial & PG & 17.9 & 19.2 & 20.7 & 19.8 & 19.9 & 18.9 & 19.9 & 20.1 & 20.8 & 20.3 & & & & & & & & \\
\hline C3\% & $\mathrm{CG}$ & 19.5 & 21.1 & 20.4 & 20.5 & 19.9 & 20.0 & 19.1 & 19.6 & 19.3 & 20.7 & & & & & & & & \\
\hline ventral & $\mathrm{PG}$ & 18.0 & 19.1 & 20.6 & 20.5 & 19.8 & 19.5 & 19.9 & 20.1 & 21.1 & 20.4 & & & & & & & & \\
\hline $\mathrm{C} 4 \%$ & CG & $12.2^{*}$ & 12.1 & $12.3^{*}$ & 11.9 & 12.4 & 11.1 & 12.7 & 13.2 & $12.1^{* *}$ & 12.9 & 0.5 & 0.608 & $<0.001$ & $<0.001$ & $<0.001$ & 0.051 & 0.553 & 0.108 \\
\hline medial & $P G$ & 11.1 & 11.3 & 10.9 & 11.2 & 11.8 & 12.1 & 13.5 & 13.0 & 14.4 & 13.5 & & & & & & & & \\
\hline $\mathrm{C} 4 \%$ & CG & 12.9 & 12.6 & 13.0 & 12.8 & 13.2 & 12.0 & 13.7 & 14.3 & 12.7 & 14.5 & & & & & & & & \\
\hline ventral & PG & 11.4 & 12.5 & 11.4 & 12.4 & 12.7 & 12.5 & 13.9 & 13.2 & 14.1 & 13.6 & & & & & & & & \\
\hline iC5\% & $\mathrm{CG}$ & 2.17 & 1.70 & $2.03^{* *}$ & $1.59^{* *}$ & $1.33^{*}$ & $1.28^{* *}$ & $1.40^{* *}$ & $1.34^{* *}$ & $1.38^{*}$ & 1.04 & 0.20 & 0.015 & $<0.001$ & 0.156 & $<0.001$ & 0.834 & 0.570 & 0.062 \\
\hline medial & PG & 1.31 & 2.02 & 1.02 & 1.03 & 0.70 & 0.57 & 0.52 & 0.64 & 1.11 & 0.96 & & & & & & & & \\
\hline iC5\% & CG & 1.36 & 1.40 & 1.59 & 1.86 & 1.28 & 1.31 & 1.33 & 1.18 & 1.31 & 1.17 & & & & & & & & \\
\hline ventral & $P G$ & 1.46 & 1.79 & 1.14 & 1.06 & 0.74 & 0.49 & 0.43 & 0.49 & 0.59 & 0.58 & & & & & & & & \\
\hline C5\% & CG & 0.64 & 0.57 & 0.76 & 0.48 & 0.53 & 0.24 & 0.60 & 0.56 & 0.57 & 0.57 & 0.10 & 0.067 & 0.011 & 0.057 & 0.150 & 0.362 & 0.024 & 0.146 \\
\hline medial & PG & 0.37 & 0.57 & 0.47 & 0.38 & 0.32 & 0.21 & 0.44 & 0.53 & 0.84 & 0.58 & & & & & & & & \\
\hline $\mathrm{C} 5 \%$ & CG & 0.51 & 0.39 & 0.49 & 0.49 & 0.53 & 0.33 & 0.57 & 0.56 & 0.42 & 0.60 & & & & & & & & \\
\hline ventral & $\mathrm{PG}$ & 0.27 & 0.45 & 0.40 & 0.35 & 0.33 & 0.29 & 0.21 & 0.19 & 0.33 & 0.32 & & & & & & & & \\
\hline
\end{tabular}

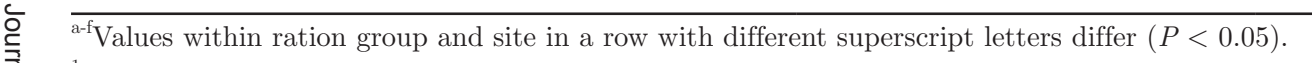

D. ${ }^{1}$ Molar proportions in \% of total VFA; $\mathrm{C} 2=$ acetic acid; $\mathrm{C} 3=$ propionic acid; $\mathrm{C} 4=$ butyric acid; iC5 $=$ iso-valeric acid; $\mathrm{C} 5=$ valeric acid

O ${ }^{2} \mathrm{CG}=$ confinement group; $\mathrm{PG}=$ pasture group; the CG stayed on a TMR-based ration during the entire trial, whereas the PG was slowly introduced to a pasture-based ration:

wh 1: TMR; wk 2: TMR and $3 \mathrm{~h}$ pasture/d; wk 3 and 4: TMR and $12 \mathrm{~h}$ pasture/d; wk 5 to 10: pasture and $1.75 \mathrm{~kg}$ of DM concentrate/d.

₹ $\quad{ }^{3} \mathrm{PSEM}=$ pooled standard error of the means; $\mathrm{G}=$ group, $\mathrm{T}=$ time; $\mathrm{L}=$ location

$\mathscr{N} \quad \dagger P<0.10$; ${ }^{*} P<0.05$; ${ }^{*} P<0.01$; symbols indicate difference between groups in particular week (within particular location if applicable). 
quent increase until wk $9(0.70 \%, P<0.001)$, causing a time and time $\times$ location effect.

$\mathrm{NH}_{3}-\mathrm{N}$ Concentrations. The $\mathrm{NH}_{3}-\mathrm{N}$ concentrations were influenced by a time effect and group $x$ time, time $\times$ location, and group $\times$ time $\times$ location interactions (Figure 1D). No relevant changes were observed in the CG. In the PG, a 2- to 4-fold increase was observed in wk 4 and 9 medially as well as ventrally, leading to significant differences between groups in these weeks.

LPS. Both groups showed a similar development of rumen LPS concentrations over the course of the trial as indicated by the significant time effect and absence of any significant interactions (Figure 1E). Between wk 1 and 3, a decrease was observed followed by an increase from wk 4 until wk 6 . Thereafter, LPS concentrations continuously decreased until wk 10. A tendency for a group $\times$ time interaction was observed due to a significant difference between groups in wk 5 (CG higher, $P=0.012$ ) and wk 10 (PG higher, $P=$ 0.023). The significant location effect indicated that on average the LPS concentrations were higher ventrally than medially. Medial and ventral LPS concentrations correlated positively with THI (medial, $\mathrm{r}=0.45, P=$ 0.045; ventral, $\mathrm{r}=0.52, P=0.018)$.

Serum glucose concentrations exhibited a similar development in both groups $\left(P_{\text {Group }}=0.113, P_{\text {Time }}<\right.$ $0.001, P_{\mathrm{G} \times \mathrm{T}}=0.427$, data not shown; similar development in fistulated and nonfistulated animals; sample collection and analysis, and data described in Schären et al., 2016) and correlated negatively with rumen LPS concentrations (medial: $\mathrm{r}=-0.59, P=0.006$, ventral: $\mathrm{r}=-0.68, P<0.001)$.

\section{Rumen Content}

Total rumen content averaged $84.7 \pm 12.8 \mathrm{~kg}$ (mean $\pm \mathrm{SD})$ with an average DM content of $134 \pm 18 \mathrm{~g} / \mathrm{kg}$ (mean $\pm \mathrm{SD}$ ) over the course of the trial and groups (Figure 2A). Rumen DM content was influenced by a time and group $\times$ time effect due to a lower DM content in the PG in wk 5 compared with wk 1 and 10 and a lower DM content in PG than CG in wk 5 (7.1 vs. $10.2 \mathrm{~kg}$ of DM). Within the CG, time did not affect rumen DM content. Rumen non-DM content exhibited a group $\times$ time interaction due to a lower non-DM content in the PG in wk 5 compared with wk 1 and 10 , whereas non-DM content in CG did not differ in time.

\section{Rumen Papillae Collection}

The average mean papilla surface area was $0.64 \pm$ $0.07 \mathrm{~cm}^{2}$ (one side) and exhibited a significant group $\times$ time $\times$ location interaction (Figure 2B). A lower papillae area was observed in wk 5 in the PG at the location saccus cecus caudodorsalis $(P<0.05)$ and saccus ventralis $(P=0.10)$ compared with wk 1 . In the CG, the mean papillae area decreased over the course of the trial at the locations saccus ventralis and saccus cecus caudoventralis. Papillae surface area was significantly lower in wk 5 for PG compared with GC at the location saccus cecus caudodorsalis. Total rumen DM content and total mean papillae area correlated significantly ( $\mathrm{r}$ $=0.54, P<0.001)$.

Histopathological analysis of rumen papillae revealed either no visible lesions, or a minimal or moderate focal or multifocal purulent-pustular inflammation in the epithelium, and minimal or moderate focal or multifocal lymphoplasmacellular infiltrates, either with or without neutrophils, in the lamina propria. Examples of inflammatory lesions are depicted in Figure 3. A higher number of tissue samples with inflammatory lesions in the PG were observed in wk 5 compared with wk 1 , and in wk 5 a higher number of samples with lesions were present in PG than in CG, at the location saccus cecus caudodorsalis (Figure 2C).

\section{VFA Absorption Test}

The $\mathrm{pH}$ of the buffer solution increased linearly during the 60-min incubation period and is described as follows: $\mathrm{pH}=5.01 \pm 0.03+0.031 \pm 0.001 \times$ time (min) $(\mathrm{r}=0.96 ; P<0.001)$. The linearity of the $\mathrm{pH}$ increase over time was further confirmed by continuous $\mathrm{pH}$ assessment during the incubation period in wk 10 (data not shown). For end $\mathrm{pH}$, time as well as group $\times$ time effects were significant (Figure 2D). In the PG, a lower end $\mathrm{pH}$ was observed in wk 5 compared with wk 1 and 10, and in wk 10 compared with wk 1 . In wk 5, end $\mathrm{pH}$ was also lower in PG than in CG (6.53 vs. 6.91). In the $\mathrm{CG}$, a decrease in end $\mathrm{pH}$ was observed over the course of the trial. Papillae area at the 3 locations as well as the mean papillae area correlated with the end $\mathrm{pH}$ of the buffer solution (saccus cecus caudodorsalis: $\mathrm{r}$ $=0.52, P=0.004$; saccus ventralis: $\mathrm{r}=0.62, P<0.001$; saccus cecus caudoventralis: $\mathrm{r}=0.53, P=0.003$; mean: $\mathrm{r}=0.66, P<0.001)$. Buffer solution VFA concentrations at the beginning of the incubation were $100.2 \pm$ $5.7 \mathrm{mmol} / \mathrm{L}$ of $\mathrm{C} 2,41.1 \pm 2.6 \mathrm{mmol} / \mathrm{L}$ of $\mathrm{C} 3$, and 23.4 $\pm 1.5 \mathrm{mmol} / \mathrm{L}$ of $\mathrm{C} 4$ (mean $\pm \mathrm{SD}$ ). For the end concentrations of $\mathrm{C} 2, \mathrm{C} 3$, and $\mathrm{C} 4$, a time effect as well as a group $\times$ time interaction was observed (Figure $2 \mathrm{E}$ ). In the PG, higher $\mathrm{C} 2$ concentrations were observed in wk 5 compared with wk 1 and 10, and in wk 5 C2 concentrations were higher in PG than in CG (71.5 vs. $55.6 \mathrm{mmol} / \mathrm{L}$ ). In the $\mathrm{CG}$, an increase occurred over 
A.

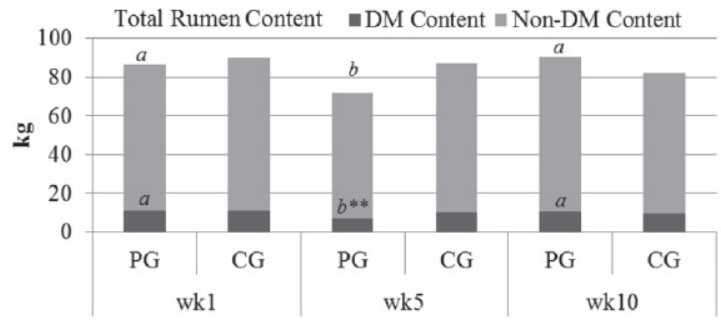

B.

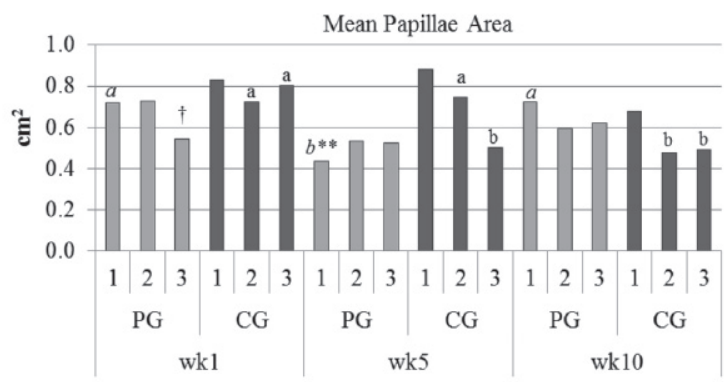

C.

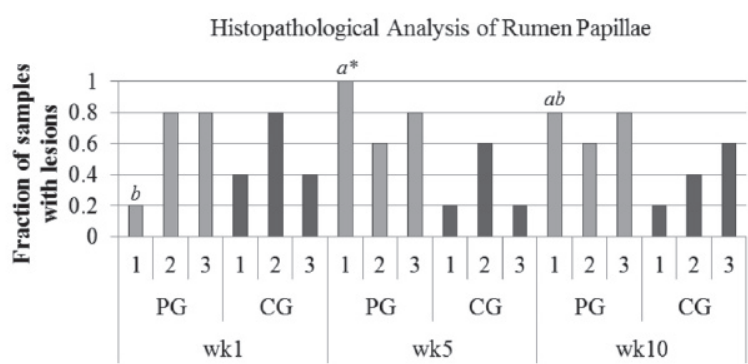

D.

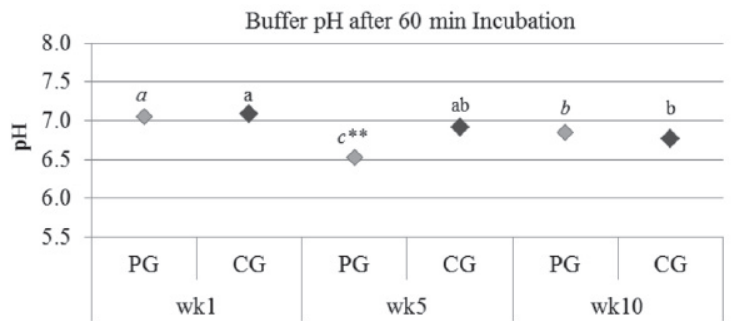

E.

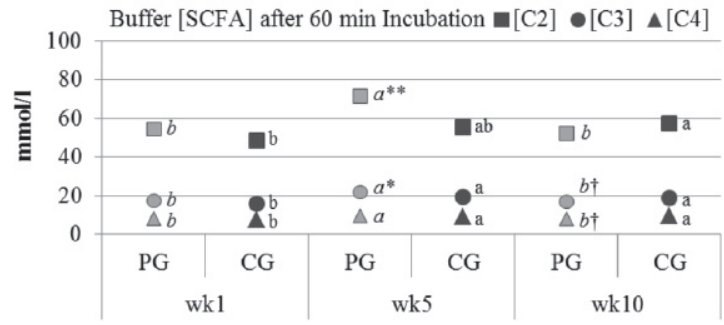

F.

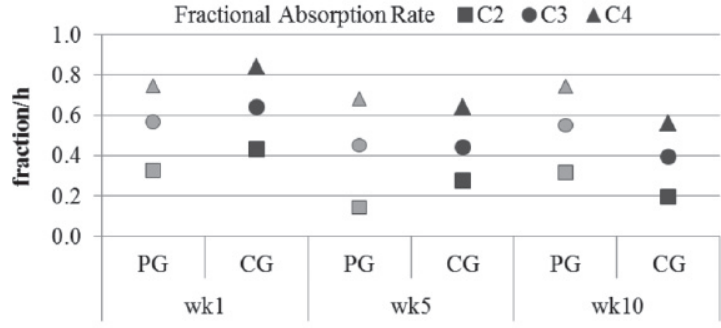

G.

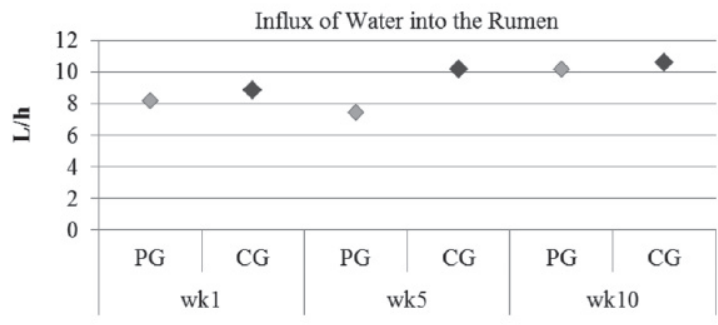

H.

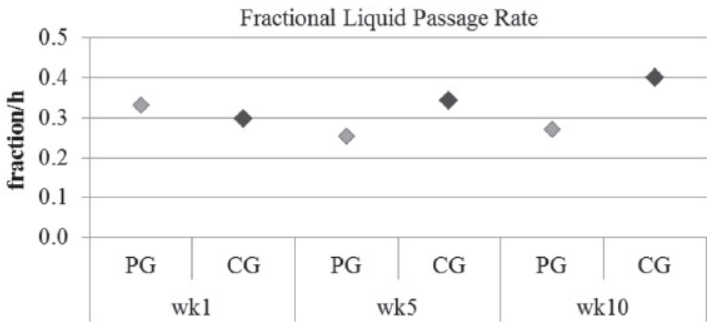

Figure 2. Effect of ration change from TMR to pasture on different rumen variables measured in wk 1, 5, and 10 of the trial. Confinement group (CG); pasture group (PG). Numbers in graphs B and C indicate different locations within the rumen: $1=$ saccus cecus caudodorsalis, 2 $=$ saccus ventralis, $3=$ saccus cecus caudoventralis. (A) Rumen content. Dry matter content: pooled SEM (PSEM) $=0.7$, significance: group $(\mathrm{G}): P=0.339$, time $(\mathrm{T}): P=0.001, \mathrm{G} \times \mathrm{T}: P=0.006$; non-DM content: $\mathrm{PSEM}=5.0$, significance: group: $P=0.703$, time: $P=0.084, \mathrm{G} \times \mathrm{T}: P$ $=0.008$. (B) Mean papillae area. $\mathrm{PSEM}=0.07$. Significance: group: 0.417 , time: $P=0.116$, location $(\mathrm{L}): P=0.069, \mathrm{G} \times \mathrm{T}: P=0.077 ; \mathrm{G} \times \mathrm{L}: P$ $=0.330 ; \mathrm{T} \times \mathrm{L}: P=0.456, \mathrm{G} \times \mathrm{T} \times \mathrm{L}: P=0.023$. (C) Histopathological analysis of papillae. Illustrated as fraction of samples with lesions $(\mathrm{n}=5$ per time, group, and location; statistical analysis: Fisher's exact tests). (D) pH of VFA absorption test (VFA-AT) buffer solution after incubation. PSEM $=0.09$, significance: group: $P=0.310$, time: $P<0.001, \mathrm{G} \times \mathrm{T}: P=0.003$. (E) VFA concentrations in VFA-AT buffer solution after incubation. Acetic acid (C2): PSEM $=2.8$, significance: group: $P=0.058$, time: $P=0.001, \mathrm{G} \times \mathrm{T}: P=0.005$; propionic acid $(\mathrm{C} 3):$ PSEM $=$ 0.8, significance: group: $P=0.492$, time: $P<0.001, \mathrm{G} \times \mathrm{T}: P=0.003$; butyric acid $(\mathrm{C} 4)$ : PSEM $=0.4$, significance: group: $P=0.793$, time: $P$ $=0.003, \mathrm{G} \times \mathrm{T}: P=0.014$. (F) Fractional absorption rate of VFA during VFA-AT. C2: PSEM $=0.07$, significance: group: $P<0.478$, time: $P=$ $0.085, \mathrm{G} \times \mathrm{T}: P=0.198$; $\mathrm{C} 3: \mathrm{PSEM}=0.07$, significance: group: $P=0.654$, time: $P=0.064, \mathrm{G} \times \mathrm{T}: P=0.245 ; \mathrm{C} 4: \mathrm{PSEM}=0.08$, significance: group: $P=0.548$, time: $P=0.137, \mathrm{G} \times \mathrm{T}: P=0.205$. $(\mathrm{G})$ Influx of water into the rumen during VFA-AT. PSEM $=2.0$, significance: group: $P$ $=0.482$, time: $P=0.608, \mathrm{G} \times \mathrm{T}: 0.820 .(\mathrm{H})$ Fractional liquid passage rate during VFA-AT. PSEM $=0.07$, significance: group: $P=0.247$, time: $P=0.860, \mathrm{G} \times \mathrm{T}: P=0.471 ; \mathrm{LSM} ; \mathrm{n}=5$. Different superscripts indicate significant differences between groups in a particular week (and location in case of papilla area and histopathological analysis of papillae; $\dagger P<0.10 ;{ }^{*} P<0.05 ; * * P<0.01$ ). Letters indicate significant differences between weeks within particular group (and location in case of papilla area and histopathological analysis of papillae; $P<0.05$ ). The CG stayed on a TMR-based ration during the entire trial, whereas the PG was slowly introduced to a pasture-based ration: wk 1: TMR; wk 2: TMR and $3 \mathrm{~h}$ pasture/d; wk 3 and 4: TMR and $12 \mathrm{~h}$ pasture/d; wk 5 to 10: pasture and $1.75 \mathrm{~kg}$ of DM concentrate/d. 
the course of the trial. Similar to C2, C3 concentrations were higher in the PG in wk 5 (21.9 vs. $19.2 \mathrm{mmol} / \mathrm{L})$ and increased in the CG between wh 1 and 10. For C4 concentrations, no significant differences between groups were present in wk 5 , and patterns similar to those of $\mathrm{C} 2$ and $\mathrm{C} 3$ within groups (increase and subsequent decrease in $\mathrm{PG}$, overall increase in $\mathrm{CG}$ ) were observed. Papillae area at the location saccus cecus caudodorsalis correlated with the end concentrations of $\mathrm{C} 2$ and $\mathrm{C} 3(\mathrm{C} 2: \mathrm{r}=-0.37, P=0.045 ; \mathrm{C} 3: \mathrm{r}=-0.34$, $P=0.065)$.

Changes in FAR reflected the alterations observed in buffer solution $\mathrm{pH}$ and VFA concentrations numerically, but no significant group, time, or group $\times$ time effects were observed (Figure 2F). Papillae area at the location saccus cecus caudodorsalis correlated with the FAR of $\mathrm{C} 2(\mathrm{r}=0.34 ; P=0.065)$.

No statistical significant group, time or group $\times$ time interaction was observed for water inflow into the rumen and FLPR (Figure $2 \mathrm{G}$ and $\mathrm{H}$ ).

\section{DISCUSSION}

Recently we reported the influence of a transition from a TMR to a pasture-based ration on production and health traits $(\mathrm{n}=60$; Schären et al., 2016). In the current work, we present rumen variables and performance data collected in 10 duodenum- and rumen-fistulated cows assessed during this trial. Even though the average parity of the fistulated animals $(4.5 \pm 2.2)$ was
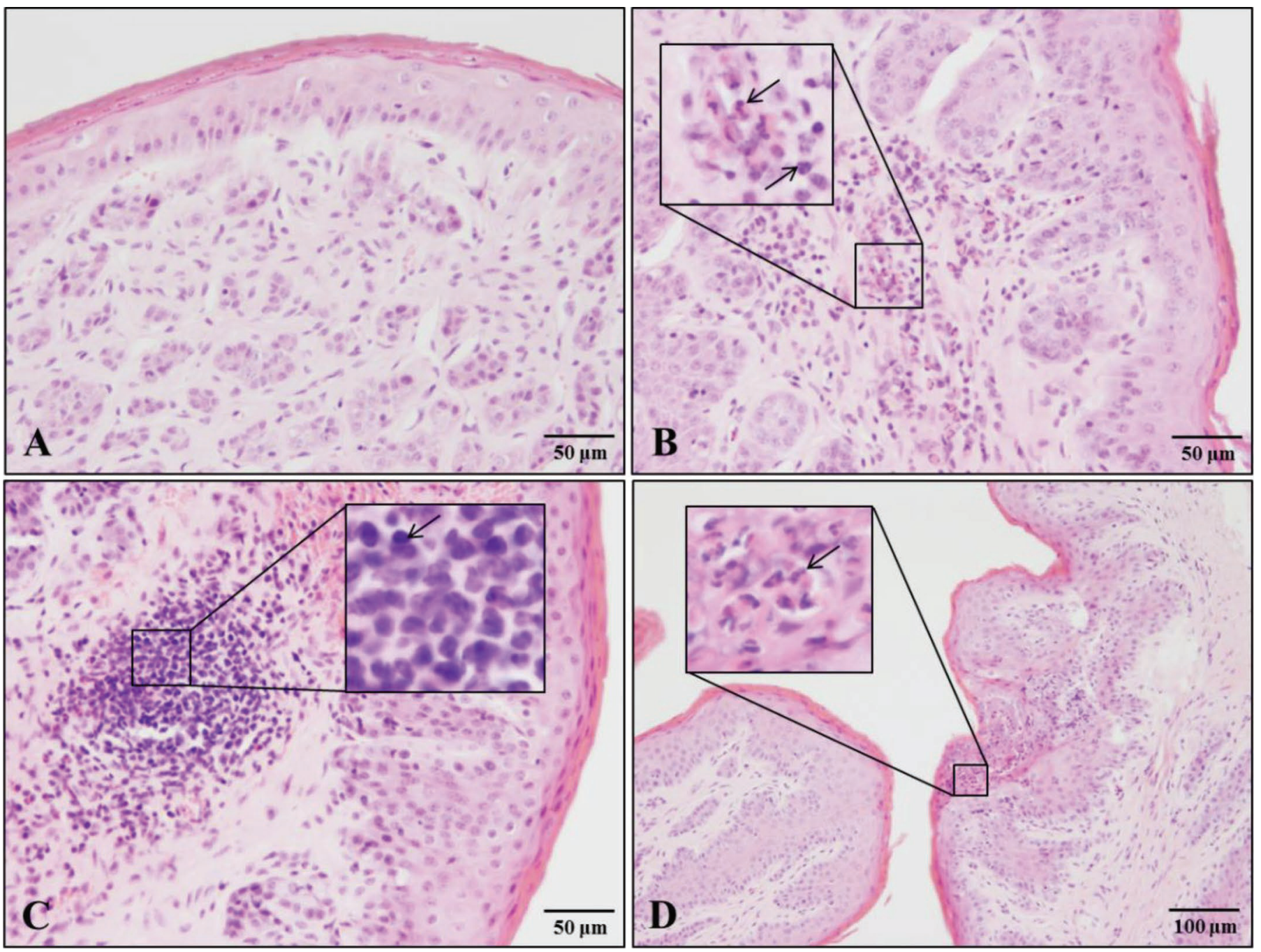

Figure 3. Examples of hematoxylin and eosin stained sections of rumen papillae. A) No lesions; B) lymphoplasmacytic (bottom arrow) and neutrophilic granulocyte (top arrow) infiltration in lamina propria; C) lymphoplasmacytic (arrow) infiltration in lamina propria; D) pustular inflammation (containing neutrophilic granulocytes, arrow) of the rumen epithelium. Color version available online. 
higher compared with the overall group $(1.9 \pm 1.6)$, in general similar alterations in animal performance were observed. Further, none of the animals were subjected to SARA challenge studies before this trial. Data on SARA risk can therefore be regarded as unbiased. The CP content of the TMR was unusually low due to unexpected poor grass silage quality. Its influence on animal performance and health has been discussed in Schären et al. (2016), and its influence on rumen variables is discussed in the relevant section of the present paper. Due to this unexpected low feed quality in the CG, we decided to place the emphasis of the discussion not only on the comparison between groups, but also on alterations within the PG over time (horizontal development).

In the 60 animals, we observed a decrease in milk production, BCS, and BW as well as an increase in milk fat content, and in serum BHB and fatty acid concentrations in the $\mathrm{PG}$ during the first weeks on a full grazing ration, indicating an energy deficit. After a few weeks on a full grazing ration, serum fatty acid concentrations and milk fat content decreased and BW increased again. We suggested that these alterations may be related to an initially decreased DMI followed by a metabolic and behavioral adaptation leading to an increase in DMI in the second half of the full-grazing period (wk 8-10). This was supported by the fact that the measured DMI on pasture in wk 7 and 9 (using the n-alkane method) were lower compared with the CG and exhibited an increase between the points in time.

We hypothesized that this ration change from a TMR to a pasture-based ration involved complex physiological and structural adaptations of the rumen. This was confirmed by alterations observed in various rumen variables presented in the current work. The lower rumen content in PG compared with CG in wk 5, which did not occur in wk 1 and 10, is in line with the assumption that DMI first decreased substantially as soon as the cows did not have access to a TMR indoors anymore and increased thereafter again. Increased clearance rate from the rumen of grass compared with TMR may also have resulted in reduced rumen contents in wk 5 . However, because total rumen content in wk 10 did not differ between PG and CG, it seems unlikely that the lower rumen fill in wk 5 can predominantly be ascribed to a faster fermentation and passage of grass compared with TMR in the rumen, and a reduced DMI in wk 5 is a more likely explanation. We assume that this change in DMI in the PG group and thereby intake of fOM led to alterations in fermentation patterns and VFA yield, which is reflected in the initial decrease of variation in rumen $\mathrm{pH}$ in wk 5 to 7 and later increase in wk 8 to 10 . We further assume that due to the increased intake of grass (being a fast fermentable substrate) throughout the trial, rumen average daily $\mathrm{pH}$ decreased continuously between wk 2 and wk 10 in the PG. This is also mirrored in total VFA concentrations, which increased in the PG from wk 7 onward, as well as in the decrease of $\mathrm{C} 2 \%$ and $\mathrm{C} 2 / \mathrm{C} 3$ and concurrent increase in $\mathrm{C} 4 \%$, indicating an increase in fermentation rate as well as the fermentation of WSC (Van Houtert, 1993; Lee et al., 2002; Storm and Kristensen, 2010).

Diets with a higher fiber content and longer particle length promote ruminal stratification (Tafaj et al., 2004; Storm and Kristensen, 2010). Storm and Kristensen (2010) stated that in low-fiber rations the rumen stratification might be less pronounced, resulting in a more homogenous ruminal content. We therefore hypothesized that a pasture-based ration in a continuous grazing system with a relatively short herbage height would lead to smaller intraruminal differences. However, none of the measured variables were indicative of a decrease in ruminal stratification. A possible reason could be the higher NDF content of the pasture compared with the TMR in our case, but further research such as the measuring of average particle length at different sites within the rumen is needed to elucidate possible interrelations.

The concurrent evolution of total rumen content and mean rumen papillae area illustrates the influence of fermentation processes on rumen papillae morphology. Several studies have shown that an increased VFA load in the rumen is a strong stimulus for papillae growth (Dirksen et al., 1984; Liebich et al., 1987; Bannink et al., 2012; Dieho et al., 2016). We therefore suggest that due to a decrease in $\mathrm{fOM}$ intake during the first days on a full grazing ration rumen papillae area decreased. Thereafter, due to an increase in ingestion of fOM in wk 8 to 10 epithelial cell proliferation was stimulated and therefore no significant difference between groups was observed in wk 10. A possible explanation for the fact that this alteration in papillae area mainly occurred at the location saccus cecus caudodorsalis could be that due to the lower rumen fill these papillae were less in contact with rumen content and thereby VFA.

Other studies have described a concurrent evolution of papillae area and VFA FAR in feed-deprived animals as well as when dietary energy intake was increased over time (Dirksen et al., 1984; Gäbel et al., 1993; Martens et al., 2012). Although ration did not significantly affect FAR, it is likely that the higher VFA concentrations and lower $\mathrm{pH}$ in the buffer solution at the end of incubation, which we observed in the PG in wk 5, indicate reduced VFA clearance related to reduced rumen papillae surface area. This is also supported by significant correlations between papillae area and buf- 
fer solution end $\mathrm{pH}$, VFA concentrations of $\mathrm{C} 2$ and $\mathrm{C} 3$, and FAR of C2. It could also be presumed that these alterations in buffer solution VFA concentrations and $\mathrm{pH}$ were caused by a decreased influx of water into the rumen and FLPR. However, because no significant alterations over the course of the trial were observed for these variables, this hypothesis seems to be unlikely.

As soon as the PG had access to pasture, milk and serum urea concentrations as well as the urine total $\mathrm{N}$ to creatinine ratio increased (details in Schären et al., 2016) due to the high CP content of the ration. We therefore also expected a concurrent increase in ruminal $\mathrm{NH}_{3}-\mathrm{N}$ concentrations, also in line with higher rumen $\mathrm{NH}_{3}-\mathrm{N}$ concentrations in cows receiving a pasture-based diet compared with a TMR (Bargo et al., 2002b) or grass silage-based (Holden et al., 1994) diet. However, no significant alterations and differences in medial and ventral ruminal $\mathrm{NH}_{3}-\mathrm{N}$ concentrations between PG and CG were observed, except for peaks in wk 4 and 9 in the PG, which cannot be correlated with any other measured variable (such as pasture CP content) or event. Further, the $\mathrm{NH}_{3}-\mathrm{N}$ concentration measured were low in comparison with other studies describing rumen fermentation variables in grazing cows (Holden et al., 1994; Bargo et al., 2002b; Taweel et al., 2004; Abrahamse et al., 2008). A possible explanation for this observation could lie in the chosen sampling time. During our trial, rumen samples were collected in the morning after milking and substantial grazing activity was prevented by rounding up the PG for milking at sunrise. Khalili and Sairanen (2000) and Soriano et al. (2000) reported similar rumen $\mathrm{NH}_{3}-\mathrm{N}$ concentrations in the morning followed by a continuous increase as soon as grazing activity started (with a 2 - to 3 -fold increase 6 to $9 \mathrm{~h}$ later).

With advancing stage of lactation, a modest reduction in milk production during the trial was expected. In the CG, however, we observed a more pronounced decrease in milk yield and BCS in particular in wk 8 to 10 of the trial, probably due to poor quality of grass silage fed in wk 5 to 10 of the trial (elaborately described in Schären et al., 2016). We suggest that several alterations observed in the CG concerning rumen fermentation, morphology, and VFA-AT can be ascribed to the decreased amount of $\mathrm{CP}$ and consequential low rumen nitrogen balance of the TMR as well. This change most certainly caused an alteration in rumen fermentation pattern and probably a decrease in fermentation rate. This is mirrored in following observations: low average $\mathrm{NH}_{3}-\mathrm{N}$ concentrations, average rumen $\mathrm{pH}$ increased, papillae area decreased, total VFA concentrations decreased, medial $\mathrm{C} 2 \%$ and $\mathrm{C} 2 / \mathrm{C} 3$ increased (except wk 10), VFA-AT buffer solution $\mathrm{pH}$ and VFA concentra- tions after incubation decreased and increased, respectively, and VFA FAR decreased numerically.

To evaluate possible risk for SARA during a ration change from TMR to pasture we assessed ruminal $\mathrm{pH}$ using continuous rumen $\mathrm{pH}$ measuring devices, and collected ruminal fluid samples to determine LPS concentrations and rumen papillae for histopathological analysis at different time points. During the transition from TMR to a pasture-based ration (wk 2-8), no increased risk for SARA was observed on either group or individual level. Rumen LPS concentrations developed similarly between groups over the course of the trial indicating an influence by a common factor such as climate condition rather than ration type. However, a higher amount of animals with samples exhibiting lesions was observed in the PG compared with the CG in wk 5 . Because this elevation in positive samples only occurred in the samples collected dorsally in the rumen and because this was also the site where the most pronounced decrease in papillae area was observed, a causal relationship with increased inflammation is not clear. Nevertheless, the concurrent observed lower ruminal VFA absorption potential suggests that the transition from a TMR to a pasture-based ration temporarily adversely affects rumen physiology. Further, a gradual decrease of rumen $\mathrm{pH}$ over the course of the trial, a numerical increase in time $\mathrm{pH}<5.8$, and individual scores based on rumen $\mathrm{pH}$ measurements in wk 9 and 10 in the PG are indicative for an increased risk for SARA on a full-grazing ration. This is in line with other studies that observed a low rumen $\mathrm{pH}$ in dairy cows on a pasture-based ration (Bramley et al., 2008; O'Grady et al., 2008). However, rumen LPS concentrations and papillae histopathology were not negatively influenced in that period. The absence of such negative effects supports the assumption of other authors that a low ruminal $\mathrm{pH}$ arising from high fOM intake from pasture does not necessarily compromise cow performance (Kolver and de Veth, 2002).

An increase in rumen LPS concentration due to an increased concentrate proportion has been elaborately described, but few data can be found on other factors that influence rumen LPS concentrations (Zebeli and Ametaj, 2009; Plaizier et al., 2012; Dänicke et al., 2014). In the previous publication, we described possible heat stress during wk 5 and between wk 7 to 8 in both groups (Schären et al., 2016). We proposed that alterations in urine creatinine and total $\mathrm{N}$ excretion as well as serum glucose concentrations observed in both groups during that time were caused by heat stress. We also observed a positive correlation between THI and rumen LPS concentrations. Therefore, we suggest that alterations in fermentation conditions in the rumen oc- 
curred in these weeks due to increased THI. Baumgard and Rhoads (2013) and Baumgard et al. (2014) suggested that the hyperinsulinemia causing a decrease in serum glucose concentrations during heat stress might be initiated by increased levels of LPS in circulation, because studies in other mammals have shown that heat-stressed animals exhibit increased gut leakage. During our trial, we observed a negative correlation between serum glucose and rumen LPS concentrations, which supports this hypothesis.

These correlations between THI and various variables illustrate the strong influence of climate conditions on dairy cow physiology. In pasture-based systems, in contrast to a confinement TMR-based system, the chemical composition of the ration (Parker and Edwards, 1996; Smit et al., 2004; Abrahamse et al., 2009), and the animals themselves (Legrand et al., 2009) are much more subject to weather and seasonal influences. We observed an interrelation between THI, pasture CP content, and metabolic urea concentrations (serum and milk urea, and urine total $\mathrm{N}$ concentrations; described in Schären et al., 2016). Further, also other factors influencing DMI and cow physiology partly depend on weather conditions as well as management (such as herbage allowance, botanical composition of pasture, pre-grazing pasture mass, supplementation strategy, grazing system, and so on; Mayne et al., 2000; Gibb, 2006; Van Vuuren and Van den Pol-Van Dasselaar, 2006). To exclude reasons other than a lower DMI for the alterations observed during this ration change, and to test whether this could be anticipated by an appropriate supplementation or grazing system, further research is needed.

\section{CONCLUSIONS}

Rumen fermentation variables indicated a decreased fermentation activity during transition from a TMR to a pasture-based ration. Concurrently, a lower rumen content, rumen papillae surface area, and potential for VFA absorption was observed. After a few weeks of a full grazing ration, fermentation activity increased and rumen content, papillae surface area, and potential for VFA absorption were similar to initial levels again. Further, a continuous decrease in mean rumen $\mathrm{pH}$ and molar acetate proportions, and an increase in molar butyrate proportions over the course of the trial was observed, which can most likely be ascribed to an increased intake of rapidly fermentable carbohydrates. Continuous rumen $\mathrm{pH}$ assessments and LPS concentrations did not reveal an increased risk for SARA during the transition period, but histopathological analysis of rumen papillae and a decreased potential for VFA absorption indicate adverse effects in the initial phase of transition. Results of the present study suggest that after behavioral and metabolic adaptation to the transition from a TMR to a pasture-based ration, no adverse effects on rumen morphology and absorption capacity occurred, although rumen $\mathrm{pH}$ after adaptation to pasture indicated increased risk of SARA. Further studies are needed to confirm these results and exclude reasons other than the ration change as causes for the alterations observed.

\section{ACKNOWLEDGMENTS}

The authors thank the Niedersächsisches Ministerium für Wissenschaft und Kultur (Hannover, Germany) for financial support. Special thanks go to Marion Burmester of the Institute for Physiology (University of Veterinary Medicine, Hanover, Germany) for the VFA analysis and Dirk Albers of the Landwirtschaftskammer Niedersachsen (Ovelgönne, Germany) for excellent consultancy and collaboration. Many thanks go to the coworkers at the Institute of Animal Nutrition and the experimental station of the Friedrich-Loeffler-Institute in Brunswick, Germany, for caring for the experimental animals, assisting with experimental measurements, as well as performing the analyses.

\section{REFERENCES}

Abrahamse, P. A., J. Dijkstra, B. Vlaeminck, and S. Tamminga. 2008. Frequent allocation of rotationally grazed dairy cows changes grazing behavior and improves productivity. J. Dairy Sci. 91:20332045.

Abrahamse, P. A., S. Tamminga, and J. Dijkstra. 2009. Effect of daily movement of dairy cattle to fresh grass in morning or afternoon on intake, grazing behaviour, rumen fermentation and milk production. J. Agric. Sci. 147:721-730.

AlZahal, O., E. Kebreab, J. France, and B. W. McBride. 2007. A mathematical approach to predicting biological values from ruminal pH measurements. J. Dairy Sci. 90:3777-3785.

Anonymous. 1998. DIN 38406-E5-2. Deutsche Einheitsverfahren zur Wasser-, Abwasser- und Schlammuntersuchung. 40. Lieferung. Weinheim: Wiley-VCH und Berlin: Beuth, Germany.

Bannink, A., W. J. J. Gerrits, J. France, and J. Dijkstra. 2012. Variation in rumen fermentation and the rumen wall during the transition period in dairy cows. Anim. Feed Sci. Technol. 172:80-94.

Bargo, F., L. D. Muller, J. E. Delahoy, and T. W. Cassidy. 2002a. Performance of high producing dairy cows with three different feeding systems combining pasture and total mixed rations. J. Dairy Sci. 85:2948-2963.

Bargo, F., L. D. Muller, G. A. Varga, J. E. Delahoy, and T. W. Cassidy. 2002b. Ruminal digestion and fermentation of high-producing dairy cows with three different feeding systems combining pasture and total mixed rations. J. Dairy Sci. 85:2964-2973.

Baumgard, L., and R. P. Rhoads. 2013. Effects of heat stress on postabsorptive metabolism and energetics. Annu. Rev. Anim. Biosci. 1:311-337.

Baumgard, L., M. Abuajamieh, S. Stoakes, M. Sanz-Fernandez, J. Johnson, R. Rhoads, and M. Eastridge. 2014. Feeding and managing cows to minimize heat stress. Pages 61-74 in Proc. 23rd 
Tri-State Dairy Nutrition Conference, Fort Wayne, Indiana. Ohio State University, Ames.

Bramley, E., I. Lean, W. Fulkerson, M. Stevenson, A. Rabiee, and N. Costa. 2008. The definition of acidosis in dairy herds predominantly fed on pasture and concentrates. J. Dairy Sci. 91:308-321.

Calsamiglia, S., M. Blanch, A. Ferret, and D. Moya. 2012. Is subacute ruminal acidosis a $\mathrm{pH}$ related problem? Causes and tools for its control. Anim. Feed Sci. Technol. 172:42-50.

Colman, E., B. M. Tas, W. Waegeman, B. De Baets, and V. Fievez. 2012. The logistic curve as a tool to describe the daily ruminal $\mathrm{pH}$ pattern and its link with milk fatty acids. J. Dairy Sci. 95:58455865.

Connor, E. E., R. W. Li, R. L. Baldwin, and C. Li. 2010. Gene expression in the digestive tissues of ruminants and their relationships with feeding and digestive processes. Animal 4:993-1007.

Dänicke, S., U. Meyer, J. Winkler, K. Schulz, S. Ulrich, J. Frahm, S. Kersten, J. Rehage, G. Breves, and S. Häußler. 2014. Description of a bovine model for studying digestive and metabolic effects of a positive energy balance not biased by lactation or gravidity. Arch. Anim. Nutr. 68:460-477.

de Menezes, A. B., E. Lewis, M. O'Donovan, B. F. O'Neill, N. Clipson, and E. M. Doyle. 2011. Microbiome analysis of dairy cows fed pasture or total mixed ration diets. FEMS Microbiol. Ecol. 78:256-265.

Dieho, K., A. Bannink, I. A. L. Geurts, J. T. Schonewille, G. Gort, and J. Dijkstra. 2016. Morphological adaptation of rumen papillae during the dry period and early lactation as affected by rate of increase of concentrate allowance. J. Dairy Sci. 99:2339-2352. http://dx.doi.org/10.3168/jds.2015-9837.

Dijkstra, J., H. Boer, J. Van Bruchem, M. Bruining, and S. Tamminga. 1993. Absorption of volatile fatty acids from the rumen of lactating dairy cows as influenced by volatile fatty acid concentration, $\mathrm{pH}$ and rumen liquid volume. Br. J. Nutr. 69:385-396.

Dirksen, G., H. Liebich, G. Brosi, H. Hagemeister, and E. Mayer. 1984. Morphologie der Pansenschleimhaut und Fettsäureresorption beim Rind-bedeutende Faktoren für Gesundheit und Leistung. Zentralbl. Veterinarmed. A 31:414-430.

Gäbel, G., J. R. Aschenbach, and F. Muller. 2002. Transfer of energy substrates across the ruminal epithelium: Implications and limitations. Animal Health Research Reviews/Conference of Research Workers in Animal Diseases 3:15-30.

Gäbel, G., M. Marek, and H. Martens. 1993. Influence of food deprivation on SCFA and electrolyte transport across sheep reticulorumen. J. Vet. Med. A 40:339-344

Geissler, C., M. Hoffmann, and B. Hiokel. 1976. Ein Beitrag zur gaschromatographischen Bestimmung flüchtiger Fettsäuren. Arch. Anim. Nutr. 26:123-129.

Gibb, M. 2006. Chapter 8: Grassland Management with Emphasis on Grazing Behaviour. Pages 141-157 in Fresh Herbage for Dairy Cattle. A. Elgersma, J. Dijkstra, and S. Tamminga, ed. Springer, Dordrecht, the Netherlands.

Gozho, G. N., J. Plaizier, D. Krause, A. Kennedy, and K. Wittenberg. 2005. Subacute ruminal acidosis induces ruminal lipopolysaccharide endotoxin release and triggers an inflammatory response. J. Dairy Sci. 88:1399-1403.

Holden, L. A., L. Muller, G. Varga, and P. Hillard. 1994. Ruminal digestion and duodenal nutrient flows in dairy cows consuming grass as pasture, hay, or silage. J. Dairy Sci. 77:3034-3042.

Khafipour, E., D. Krause, and J. Plaizier. 2009a. Alfalfa pellet-induced subacute ruminal acidosis in dairy cows increases bacterial endotoxin in the rumen without causing inflammation. J. Dairy Sci. 92:1712-1724

Khafipour, E., D. Krause, and J. Plaizier. 2009b. A grain-based subacute ruminal acidosis challenge causes translocation of lipopolysaccharide and triggers inflammation. J. Dairy Sci. 92:1060-1070.

Khalili, H., and A. Sairanen. 2000. Effect of concentrate type on rumen fermentation and milk production of cows at pasture. Anim. Feed Sci. Technol. 84:199-212.

Kolver, E. S. 2003. Nutritional limitations to increased production on pasture-based systems. Proc. Nutr. Soc. 62:291-300.
Kolver, E. S., and M. J. de Veth. 2002. Prediction of ruminal pH from pasture-based diets. J. Dairy Sci. 85:1255-1266.

Lee, M. R. F., L. J. Harris, J. M. Moorby, M. O. Humphreys, M. K. Theodorou, J. C. MacRae, and N. D. Scollan. 2002. Rumen metabolism and nitrogen flow to the small intestine in steers offered Lolium perenne containing different levels of water-soluble carbohydrate. Anim. Sci. 74:587-596.

Legrand, A. L., M. A. von Keyserlingk, and D. M. Weary. 2009. Preference and usage of pasture versus free-stall housing by lactating dairy cattle. J. Dairy Sci. 92:3651-3658.

Liebich, H. G., G. Dirksen, A. Arbel, S. Dori, and E. Mayer. 1987. Fütterungsabhängige Veränderungen der Pansenschleimhaut von Hochleistungskühen im Zeitraum von der Trockenstellung bis acht Wochen post partum. J. Vet. Med. A 34:661-672.

Littell, R. C., G. A. Milliken, W. W. Stroup, R. D. Wolfinger, and O. Schabenberger. 2006. SAS for Mixed Models, 2nd ed. SAS Institute Inc., Cary, NC.

Martens, H., I. Rabbani, Z. M. Shen, F. Stumpff, and C. Deiner. 2012. Changes in rumen absorption processes during transition. Anim. Feed Sci. Technol. 172:95-102.

Mayne, C. S., I. A. Wright, and G. E. J. Fisher. 2000. Chapter 10: Grassland management under grazing and animal response. Pages 229-246 in Grass: Its Production and Utilization. A. Hopkins, ed. Blackwell Science Ltd., Oxford, UK.

Nakano, M. H. S., M. Tohno, K. Matoba, R. Uegaki, and H. Ishizaki. 2013. Variation of rumen bacterial diversity in steers after the beginning of grazing. Pages 591-592 in Proc. 22nd Int. Grassland Congress. New South Wales Department of Primary Industry, Orange New South Wales, Sydney, Australia.

O'Grady, L., M. L. Doherty, and F. J. Mulligan. 2008. Subacute ruminal acidosis (SARA) in grazing Irish dairy cows. Vet. J. 176:44-49.

Osuji, P. O. 1974. Physiology of eating and energy expenditure of ruminant at pasture. J. Range Manage. 27:437-443.

Parker, W., and N. Edwards. 1996. Within-year variation in pasture quality has implications for dairy cow nutrition. Proc. New Zealand Grassl. Assoc. 57:173-177.

Penner, G. B., K. Beauchemin, and T. Mutsvangwa. 2006. An evaluation of the accuracy and precision of a stand-alone submersible continuous ruminal pH measurement system. J. Dairy Sci. 89:2132-2140.

Penner, G. B., M. A. Steele, J. R. Aschenbach, and B. W. McBride. 2011. Ruminant Nutrition Symposium: Molecular adaptation of ruminal epithelia to highly fermentable diets. J. Anim. Sci. 89:1108-1119.

Plaizier, J., E. Khafipour, S. Li, G. Gozho, and D. Krause. 2012 Subacute ruminal acidosis (SARA), endotoxins and health consequences. Anim. Feed Sci. Technol. 172:9-21.

Plaizier, J., D. Krause, G. Gozho, and B. McBride. 2008. Subacute ruminal acidosis in dairy cows: The physiological causes, incidence and consequences. Vet. J. 176:21-31.

Russell, J. B., and J. L. Rychlik. 2001. Factors that alter rumen microbial ecology. Science 292:1119-1122.

Schären, M., S. Jostmeier, S. Ruesink, L. Hüther, J. Frahm, M. Bulang, U. Meyer, J. Rehage, J. Isselstein, G. Breves, and S. Dänicke. 2016. The effects of a ration change from a total mixed ration to pasture on health and production of dairy cows. J. Dairy Sci. 99:1183-2000. http://dx.doi.org/10.3168/jds.2015-9873.

Smit, H., A. Elgersma, A. Lúscher, B. Jeangros, W. Kessler, O Huguenin, M. Lobsiger, N. Millar, and D. Suter. 2004. Diurnal fluctuations in vertical distribution of chemical composition in a perennial ryegrass (Lolium perenne L.) sward during the season. Pages 951-953 in Proc. 20th General Meeting of the European Grassland Federation. Luzern, Switzerland. vdf Hochschulverlag AG, ETH Zurich.

Soriano, F. D., C. E. Polan, and C. N. Miller. 2000. Milk production and composition, rumen fermentation parameters, grazing behavior of dairy cows supplemented with different forms and amounts of corn grain. J. Dairy Sci. 83:1520-1529.

Steele, M. A., J. Croom, M. Kahler, O. AlZahal, S. E. Hook, K. Plaizier, and B. W. McBride. 2011. Bovine rumen epithelium under- 
goes rapid structural adaptations during grain-induced subacute ruminal acidosis. Am J. Physiol. Reg. I. 300:R1515-R1523.

Steele, M. A., L. Dionissopoulos, O. AlZahal, J. Doelman, and B. W. McBride. 2012. Rumen epithelial adaptation to ruminal acidosis in lactating cattle involves the coordinated expression of insulin-like growth factor-binding proteins and a cholesterolgenic enzyme. J. Dairy Sci. 95:318-327.

Storm, A. C., and N. B. Kristensen. 2010. Effects of particle size and dry matter content of a total mixed ration on intraruminal equilibration and net portal flux of volatile fatty acids in lactating dairy cows. J. Dairy Sci. 93:4223-4238.

Tafaj, M., B. Junck, A. Maulbetsch, H. Steingass, H. P. Piepho, and W. Drochner. 2004. Digesta characteristics of dorsal, middle and ventral rumen of cows fed with different hay qualities and concentrate levels. Arch. Anim. Nutr. 58:325-342.

Taweel, H., B. Tas, J. Dijkstra, and S. Tamminga. 2004. Intake regulation and grazing behavior of dairy cows under continuous stocking. J. Dairy Sci. 87:3417-3427.
Van Houtert, M. 1993. The production and metabolism of volatile fatty acids by ruminants fed roughages: A review. Anim. Feed Sci. Technol. 43:189-225.

Van Vuuren, A. M., and A. Van den Pol-Van Dasselaar. 2006. Chapter 5: Grazing Systems and Feed Supplementation. Pages 85-101 in Fresh Herbage for Dairy Cattle. A. Elgersma, J. Dijkstra, and S. Tamminga, ed. Springer, Dordrecht, the Netherlands.

Zebeli, Q., and B. N. Ametaj. 2009. Relationships between rumen lipopolysaccharide and mediators of inflammatory response with milk fat production and efficiency in dairy cows. J. Dairy Sci. 92:3800-3809.

Zebeli, Q., J. Dijkstra, M. Tafaj, H. Steingass, B. N. Ametaj, and W. Drochner. 2008. Modeling the adequacy of dietary fiber in dairy cows based on the responses of ruminal $\mathrm{pH}$ and milk fat production to composition of the diet. J. Dairy Sci. 91:2046-2066. 